American University Washington College of Law

Digital Commons @ American University Washington College of

Law

Articles in Law Reviews \& Other Academic Journals

Scholarship \& Research

1999

\title{
Lawyers' Duty to Do Justice: A New Look at the History of the 1908 Canons
}

Susan Carle

American University Washington College of Law, scarle@wcl.american.edu

Follow this and additional works at: https://digitalcommons.wcl.american.edu/facsch_lawrev

Part of the Legal Ethics and Professional Responsibility Commons, Legal History Commons, and the Legal Profession Commons

\section{Recommended Citation}

Carle, Susan, "Lawyers' Duty to Do Justice: A New Look at the History of the 1908 Canons" (1999).

Articles in Law Reviews \& Other Academic Journals. 1529.

https://digitalcommons.wcl.american.edu/facsch_lawrev/1529

This Article is brought to you for free and open access by the Scholarship \& Research at Digital Commons @ American University Washington College of Law. It has been accepted for inclusion in Articles in Law Reviews \& Other Academic Journals by an authorized administrator of Digital Commons @ American University Washington College of Law. For more information, please contact kclay@wcl.american.edu. 


\section{Lawyers' Duty to Do Justice: A New Look at the History of the 1908 Canons}

\section{Susan D. Carle}

This article examines a long-forgotten controversy about lawyers' duties to evaluate the justice of their clients' causes in civil cases that took place among the members of the Committee of the American Bar Association (ABA) that drafted the 1908 Canons of Professional Responsibility. The article presents an analysis of newly discovered internal working documents of this important, but never before examined, ABA committee, supplemented with primary historical research into the views and backgrounds of the committee's members. The article demonstrates how a clash of perspectives among these men-traceable in part to their backgrounds but also to their unpredictable allegiances to conflicting trends in legal thought at the turn of the centuryprevented the committee from reaching a satisfactory resolution on the dutyto-do-justice issue. The committee members instead adopted ineffectual compromise language in the Canons, leaving us with a legacy of concealed ambivalence on the question of lawyers" "duty to do justice" in civil cases.

It is not easy to see moral ideals change. The alteration of assumptions is too subtle, the shifting foundations of guilt and pride too nearly invisible. But when the moral life moves-like a deer in snow-bound woods-it leaves tracks, and we can know where it has been even if we do not see the thing itself.

-Michael Schudson 1977

Susan D. Carle is assistant professor of law, American University, Washington College of Law; W.M. Keck Foundation Fellow in Legal Ethics at the Georgetown University Law Center (GULC), 1995-97. I am grateful to the W.M. Keck Foundation and GULC for providing the funding that made this research possible. Professors Robert Drinan, Dan Ernst, Carrie Menkel-Meadow, Doug Parker, and Mitt Regan, all of GULC, provided invaluable feedback on earlier drafts, as did Robert Gordon, Robert MacCrate, and Clyde Spillenger. Generous research assistance funding from American University made possible the expert assistance of Gina K. Janiero in preparing the bibliography. 
Perhaps no issue in legal ethics has been debated more often, and resolved less satisfactorily, than that of lawyers' duties-in civil cases-to concern themselves with the "justice" of their client's cause. ${ }^{1}$ The issue arises in the representation of any client, but can take on special importance when the lawyer represents an organization that wields large-scale social, political, or economic power. Thus, at least since the rise of large-scale organizations in American society during the nineteenth century, the American public and its legal profession have been debating lawyers' ethical duties to monitor the justice of the causes their clients wish them to pursue. Often, however, participants in each new round of this debate have failed to appreciate what took place during the rounds before. This article aims to increase that historical appreciation by examining a long-forgotten controversy about lawyers' duties to evaluate the justice of their clients' causes that took place among the members of the American Bar Association's (ABA) Committee on Code of Professional Ethics ("Ethics Committee") while it was drafting the first national model canons of legal ethics, enacted in 1908 ("1908 Canons").

This article argues that an examination of this committee's internal debate on lawyers' duties to monitor the justice of their clients' causes contributes an important new dimension to our understanding of this continuing preoccupation in our legal ethics literature. Legal ethics scholars appear to have wholly overlooked the existence of such controversy within the 1908 Ethics Committee, perhaps because key working papers of the committee that memorialize this debate were long ago buried within the ABA's voluminous documents collection. Having managed to retrieve this valuable historical source (Alexander 1908), I here present a detailed analysis of it, along with original historical research into the biographies and legal writings of the members of the Ethics Committee.

My aim is to explore the link between the Ethics Committee members' varying jurisprudential outlooks and their conflicting positions on whether lawyers should be held ethically accountable for the justice of their clients' causes. ${ }^{2}$ I argue that a clash of perspectives among the committee members, traceable to their allegiances to conflicting trends in legal thought at the turn of the twentieth century, prevented them from reaching a satisfactory

1. In criminal cases, the bar reached a broader (but not complete) consensus in an earlier period about the propriety of providing a vigorous defense for clients regardless of guilt or innocence, in the interests of guarding against misuse of state power. Because the historical trajectory of lawyers' thinking on the duty to do justice in the criminal context is so different, this article will in the main exclude the criminal,context from its consideration. Similarly, the bar's thinking on the propriety of lawyers vouching personally for their belief in their client's cause took a different tack, and this article therefore will not cover this issue either.

2. In undertaking this kind of empirical analysis of how the individuals who served on the 1908 committee thought about the duty-to-do-justice issue, this article seeks to respond to calls for more careful and detailed inquiry into how our legal ethics norms developed in particular sociohistorical contexts (Nelson and Trubek 1992). 
resolution on the duty-to-do-justice issue. Instead of acknowledging their differences of opinion and wrestling with the fundamental jurisprudential issues underlying their disagreement, the committee members glossed over their dispute in their public reports and adopted ineffectual compromise language in the Canons. This language, while pointing in somewhat contradictory directions on the duty-to-do-justice question, in the main evinced movement away from the view that lawyers should concern themselves with the justice of their clients' causes. The committee's debate thus captures a moment of transition in our ever-changing normative conceptions of the lawyer's role. ${ }^{3}$

This article will proceed in the following parts. Part one sketches in brief overview the contemporary debate on the duty-to-do-justice issue. Part two examines the social, political, and intellectual setting in which the 1908 ABA Ethics Committee began its task of drafting the first national model code of legal ethics. Part three analyzes the committee's internal debate and traces how the participants' divergent intellectual commitments played themselves out in that debate in unpredictable and transfigurative ways. Finally, part four describes the manner in which the committee resolved its differences on the duty-to-do-justice issue, and suggests some of the implications of the committee's actions for our current debate on this question.

\section{THE CONTEMPORARY DEBATE ON LAWYERS' DUTY TO EVALUATE THE JUSTICE OF THEIR CLIENTS' CAUSES}

Few would disagree with the claim that the contemporary American bar is profoundly ambivalent about the extent to which lawyers should concern themselves with the justice of their clients' claims. This issue likewise lies at the heart of the contemporary academic debate in legal ethics. The participants in this flourishing scholarly debate can be roughly divided into two contrasting positions, sometimes referred to as the "nonaccountability" and the "moral activist" approaches. ${ }^{4}$ In briefest outline, these two positions are as follows:

3. It bears note that I am not here attempting to examine how the lawyers I study actually behaved in practice; my focus in this article is, instead, on these lawyers' stated ideals. The degree of connection between such stated ideals and lawyers' actual practices is of course a separate question, and one not susceptible to analysis without more detailed evidence than is available about the 1908 Ethics Committee members. But these lawyers' stated ideals about how practice should be conducted are illuminating in their own right in what they reflect about their professional self-conceptions. It is that limited question-of lawyers' ethics at the level of rhetoric - that this article seeks to address.

4. Of course, the positions of participants in this contemporary discussion are more complex than this binary characterization reflects, but an oversimplified sketch is sufficient for these background purposes. 


\section{A. The Nonaccountability View}

The nonaccountability view maintains that lawyers have no business inquiring into the justice or morality of their clients' causes. This is arguably the prevailing view within the contemporary American private bar and, as many commentators have observed, is the predominant-though not exclusive-sentiment reflected in the ABA's Model Rules of Professional Conduct ("Model Rules") (Luban 1988, app. A). A number of the model rules, including Rules $1.2(\mathrm{a})^{5}$ and $1.2(\mathrm{~b}),{ }^{6}$ explicitly endorse the nonaccountability view, and the ABA's Model Code of Professional Responsibility contains many similar provisions. ${ }^{7}$ Other provisions of the Model Rules and Model Code, including the lawyer's strict duty to hold her client's secrets in confidence and the lawyer's duty of loyalty to her client, implicitly embrace the nonaccountability view. ${ }^{8}$ Charles Fried (1976) has presented the classic academic formulation of the position, and many other scholars have embraced the nonaccountability perspective with some variations or qualifications (Pepper 1986; Wolf 1983; Schneyer 1991; Freedman 1991).

For all of its fit with our contemporary preoccupations with moral relativism and the positionally determined nature of "truth," the nonaccountability view is profoundly troubling. It necessarily produces generations of lawyers who think of themselves as "hired guns"-who feel no moral qualms about selling their services to the highest bidders and then carrying out those clients' purposes ("within the law," technically speaking) with no regard for the social consequences of their efforts. ${ }^{9}$ That a professional group as large, powerful, privileged, and talented as the American bar

5. "A lawyer shall abide by a client's decisions concerning the objectives of representation. ..."

6. "A lawyer's representation of a client ... does not constitute an endorsement of the client's political, economic, social or moral views or activities."

7. See, e.g., Model Code DR 7-101(A)(1) ("[a] lawyer shall not intentionally ... [f]ail to seek the lawful objectives of his clients through reasonably available means"); EC 7-7 ("In certain areas of legal representation not affecting the merits of the cause or substantially prejudicing the rights of a client, a lawyer is entitled to make decisions on his own. But otherwise the authority to make decisions is entirely that of the client"); EC 7-8 ("In the final analysis . . . the lawyer should always remember that the decision whether to forgo legally available objectives or methods because of non-legal factors is ultimately for the client and not for himself").

8. What does not appear in the ABA Model Rules'is also significant on this score, as for example, in the defeat of a proposal offered during the debates on Model Rule 1.13 to add "whistle-blower" privileges for lawyers who are unsuccessful in using internal persuasion to halt serious wrongdoing by organizational clients (Schneyer 1992, 95).

The position that lawyers have no business evaluating the justice of their clients' causes is closely associated with the concepts of "adversarial" ethics, "neutrality and partisanship," "client autonomy," and other similar formulations (Schwartz 1978; Luban 1988, 11-30, 50 . 103).

9. I am, of course, far from the first to point out this implication of the nonaccountability view (see, e.g., Wasserstrom 1975). 
should conceive of its professional responsibilities in such an antisocial manner has deeply disturbing implications, implications that have led some of the most thoughtful and creative legal ethics scholars writing today to propose alternative visions of lawyers' professional obligations. These visions can be roughly lumped together as the "moral activist" view.

\section{B. The Moral Activist View}

The eclectic group of scholars who oppose the nonaccountability view espouse a great many positions on lawyers' duties to concern themselves with the justice of their clients' causes. One predominant voice in this literature comes from moral philosophy. Philosopher and law professor David Luban is perhaps the leading proponent of this approach. Calling for a return to Progressive Era conceptions of lawyers' ethical duties, Luban draws on historical icons such as Louis Brandeis as exemplars of how lawyers should seek to do justice through law. ${ }^{10}$ Luban argues for a vision of "moral activist" lawyering under which contemporary lawyers would emulate earlier lawyers who reputedly represented powerful clients but insisted that these clients take the morally correct path in resolving their legal affairs. Luban's ideal lawyer would "discuss [with] the client the rightness or wrongness of her projects, and the possible impact of those projects on 'the people,' in the same matter-of-fact and (one hopes) unmoralistic manner that one discusses the financial aspects of a representation" (Luban 1988, 173). Luban further argues that such an ethical lawyer should "challenge her client if the representation seems to her morally unworthy; she may cajole or negotiate with the client to change the ends or means; she may find herself compelled to initiate action that the client will view as betrayal; and she will not fear to quit" (Luban 1988, xxii).

Acknowledging that his vision is in sharp conflict with today's predominant ethic of client loyalty, Luban goes so far as to call on lawyers to violate their pledge of client confidentiality where harm to society is resulting from their clients' acts (ongoing or past). Especially in the context of representing corporations, Luban advocates enthusiastic whistle-blowing as an important option in handling recalcitrant clients $(1988,233)$.

Closely allied with Luban's view are those of critical legal studies scholar William H. Simon and historian Robert Gordon. Simon argues for a vision of ethical lawyering involving a "discretionary approach," through which lawyers should seek to "do justice" by calibrating their actions on behalf of a client to accord with their assessments of both the "internal merit" of the client's case and its "relative merits" in relation to the interests

10. For a summary of legal ethics literature that exalts Brandeis in this fashion, see Spillenger 1996, 1471-76. 
of other affected parties (Simon 1988, 1090-1120)."1 Similarly, Gordon has drawn on his research on the turn-of-the-century American corporate bar to argue for a return to what he terms a "Progressive lawyer-statesman" role (Gordon 1990, 263-67; 1988, 25-30, 71-73; 1984).

Legal ethics scholars in the moral activist school are on point, I believe, in expressing deep concern about the problematic implications of the nonaccountability approach. But I will suggest here that the origins of the divide between the nonaccountability and moral activist views are deeper and more complicated than the moral activists sometimes assume. Lawyers' ambivalence on the duty-to-do-justice issue did not commence with a clash between Brandeisian and corporate law conceptions of law practice in the decades surrounding the turn of the century. Instead, this article will demonstrate, the tension between the nonaccountability and moral activist approaches can be directly traced back to conflicts between certain jurisprudential trends predominant in legal ethics thinking in the early versus the later parts of the nineteenth century (trends that in turn had much deeper historical roots, as I will note in passing). The positions of the early-twentieth-century lawyers on the 1908 Ethics Committee were related in unpredictable ways to their allegiances to such competing jurisprudential outlooks; contrary to what moral activists and others have supposed, these positions did not correlate neatly with lawyers' practice settings. These findings suggest that a more complex historical legacy underlies the intractability of the current debate on the duty-to-do-justice question, and that we would do well to examine that legacy in more detail in order to more fully understand our current situation.

\section{BACKGROUND TO THE 1908 CANONS}

The ABA's Ethics Committee drafted the 1908 Canons during the heart of the Progressive Era, a time in which new ideas about science and law, and a new optimism about people's ability to change moral sentiments through study and education, were taking hold in many areas of the country. At the same time, the bar was experiencing the pressures of a changing structure of legal practice, as bigger and more specialized law firms emerged to respond to the growing demand for corporate legal services and lawyers reacted against a loss of their independent professional prestige and power. This part will sketch this social and political setting in which the ABA's

11. To do so, Simon proposes, the lawyer should assess (1) the reliability of the procedure he or she is operating within and the vulnerability or power of the other side; (2) whether a particular litigation tactic is likely to promote the adjudicator's ability to decide the case fairly; and (3) the purposes of the law, at least to the extent that this can be clearly detected and accords with fundamental values (Simon 1988, 1098-1106; see also Simon 1994, 1984, 1978). 
Ethics Committee took up the project of drafting a national model legal ethics code, and then analyze the intellectual traditions the committee drew upon in seeking to devise such a code.

\section{A. The Call for a National Legal Ethics Code}

Jerold Auerbach $(1974,14-128)$ and other historians have investigated the sociopolitical setting in which the ABA Ethics Committee undertook to draft the 1908 Canon, and depicting that setting therefore requires only a summary sketch here. The ABA, after decades of inaction, ${ }^{12}$ finally reacted to a confluence of factors in undertaking to draft a uniform model code of professional ethics for the nation's lawyers. First, the American Medical Association had drafted a revised code of professional ethics in 1903 (Starr 1982, 117), and the ABA did not want to be left behind. Second, many members of the ABA, like the rest of the country, were inspired by the spirit of the Progressive Era and possessed the hope and confidence that the moral standards of the population could be improved (Link and McCormick 1983; Rodgers 1982). This Progressive spirit blended with the longer-standing jurisprudential commitment of some elite lawyers to the development of "legal science" based on a search for basic, internally coherent principles underlying the common law (Gordon 1984, 52; 1983). That commitment had prompted lawyers during the late nineteenth century to take part in moderate reform activities to codify and purify procedural and substantive law. In the early twentieth century, some members of the ABA active in formulating its first legal ethics code saw this project as a continuation of the process of rationalizing and making manifest the general principles and evolutionary course underlying all law. ${ }^{13}$

A third impetus for drafting the Canons stemmed from the nationwide crisis the bar perceived in the public opinion about lawyers. Exploiting a popular political issue, Theodore Roosevelt had spoken before the ABA in 1905 and condemned corporate lawyers for helping their clients evade regulation. The law journals at the turn of the century were replete with articles lamenting the growing "commercialism" in law practice (Mowry 1902; Ab-

12. The ABA was founded in 1878 , during a period of huge growth in the formation of all types of voluntary associations, especially associations organized on occupational affiliations (Wiebe 1967, 129; Matzko 1984, 272; Galambos 1970, 279-90). Although improving the professional values of the bar was one of the ABA's principal avowed purposes, it did not turn its attention to developing a national code of ethics for more than two decades. For the first decades of its existence, the ABA functioned as little more than a social club, predominated by elite easterners and wealthy southern lawyers who could afford to travel to enjoy the cool temperatures and racetrack of Saratoga Springs, where organizational meetings were held (Hurst 1950, 287; Matzko 1984, 87).

13. One commentator, for example, described the canons as applied ethics, derived through empirical methods, which would be "substantially correct" after being "further rationalized" over time by having errors detected and "excrescences pruned" (Abbot 1913). 
bot 1902). Even bar leaders with strong probusiness jurisprudential commitments, such as U.S. Supreme Court Justice David Brewer (Brodhead 1994), who would soon become a member of the 1908 Ethics Committee, spoke of a growing danger of corruption of the bar by these gigantic corporate concerns (Brewer 1904a). Reacting to these prompts, the leaders of the ABA saw a need to take steps to improve their self-image. ${ }^{14}$

At the same time, a very different concern about the growing "commercialism" of law practice existed among the ABA's membership. As Jerold Auerbach (1974) has described, the tiny elitist sector of the legal profession represented by the ABA in the early 1900 s was strongly opposed to the influx of "new" lawyers into the profession, especially those from immigrant backgrounds and low socioeconomic classes who saw opportunities for social and economic advancement in pursing professional degrees. Comfortable in the business that came their way by virtue of their social connections, the lawyers who made up the membership of the ABA looked with disdain on the scrambling, ungraceful efforts to gain business engaged in by some newcomers to the bar, and condemned these lawyers for lacking proper socialization into "American" values (Auerbach 1974, 43-130; Hofstadter 1955, 155). ${ }^{15}$ As the report of the ABA Committee appointed to consider the "advisability and practicability" of the ABA's adoption of a code of professional ethics complained:

the trend of many is away from the ideals of the past and the tendency more and more to reduce our high calling to the level of a trade. . . . Once possible ostracism by professional brethren was sufficient to keep from serious error the practitioner with no fixed ideals of ethical conduct; but now the shyster, the barratrously inclined, the ambulance chaser, the member of the Bar with a system of runners, pursue their nefarious methods with no check save the rope of sand of moral suasion. (Committee on Code of Professional Ethics 1906, 600, 601)

Inspired by this mix of high-minded and less noble institutional motives, ABA President George R. Peck, an Illinois railroad lawyer, ${ }^{16}$ appointed a five-man committee in 1905, shortly after Roosevelt's speech, to consider the feasibility of drafting a code of ethics for the American bar.

14. The report of the committee formed to investigate the feasibility of drafting a model canon of legal ethics proclaimed that the very future of the country's "republican institutions" depended on "continued confidence on the part of the public in the fairness, integrity and impartiality of its administration" and on "the conduct and motives of the members of our profession, who are the high-priests of justice" (Committee on Code of Professional Ethics 1906).

15. For general theoretical analyses of the tendency of professions to adopt ideologies and other strategies that restrict entry of new members, see Abel 1989, Friedson 1986, and Larsen 1977.

16. According to one biographer, Peck was "one of a notable little coterie" prominent within the ABA who "dined, joked and cronied together for many years" (Rogers 1932, 136). 
The committee reported back the next year with a recommendation that such a code be drafted, and expanded its membership to 14 to include the retiring and incoming presidents of the ABA, U.S. Supreme Court Justice David Brewer, and Thomas Goode Jones, the author of the Alabama State Bar Association Code of Legal Ethics, which was widely viewed as the stateof-the-art legal ethics code of the time. The committee's plan, in the words of Justice Brewer, was to prepare "a body of rules, few in number, clear and precise in their provisions, so there can be no excuse for their violation, to be given operative and binding force by legislation or action of the highest courts of the states" (Committee on Code of Professional Ethics 1908, 570). Thus, the goal held by at least some of the drafters was not to create a purely aspirational code, as legal ethics scholars often assume about the $1908 \mathrm{Ca}$ nons, but to draft a set of rules that could be given enforcement teeth against those members of the profession not amenable to moral persuasion.

\section{B. The Intellectual Tradition Studied by the Committee}

In setting out to draft a model legal ethics code for all the lawyers in the nation, the committee did not start from scratch. The secretary of the committee, Lucien Alexander of Philadelphia, ${ }^{17}$ prepared an extensive annotation of the leading American nineteenth-century legal ethics authorities, which he circulated to all the committee members. This annotation provided the boilerplate materials that became the basis for a first draft of the 1908 Canons. The authorities the committee studied in this manner were of two types: First, the committee reprinted and circulated the two best known early-nineteenth-century American treatises on legal ethicsDavid Hoffman's 1836 "Fifty Resolutions for Professional Deportment" and George Sharswood's 1854 treatise titled Legal Ethics. Second, the committee studied the legal ethics codes promulgated by several state bar associations in the last decades of the nineteenth century, especially the 1887 code drafted by Thomas Goode Jones for the State Bar Association of Alabama.

Scholars who have examined these nineteenth-century influences on our legal ethics rules typically depict a smooth process in the transmission of legal ethics doctrines-a progression of congruous ideas from Hoffman and Sharswood, through the Alabama State Bar Association Code, which Jones adapted from Sharswood's treatise, to the 1908 Canons of Professional Ethics. ${ }^{18} \mathrm{I}$ argue below, however, that, at least with respect to the duty-to-do-

17. Alexander practiced in a two-person Philadelphia law firm and was active in the movement to tighten admissions requirements to the Philadelphia bar. See app. A.

18. Russell Pearce (1992) and Maxwell Bloomfield (1979), for example, both argue that civic republican principles were imported wholesale into the first state bar legal ethics codes of the late nineteenth century and from there into the 1908 Canons. L. Ray Patterson (1980), on the other hand, detects change in the concept of lawyer's duty of client loyalty and confidentiality through the nineteenth century. 
justice issue, the transmission of ideas from one generation of legal ethics authorities to the next was not nearly as harmonious as these accounts assume. To the contrary, the position of the late-nineteenth-century state bar associations was greatly at odds with the approach of Hoffman and Sharswood, and that incongruity forced the 1908 Ethics Committee to confront the duty-to-do-justice issue anew. In order to appreciate this importantand completely overlooked-aspect of the intellectual history of the 1908 Canons, we must digress at some length to consider the two divergent approaches to the duty-to-do-justice issue reflected in the nineteenth-century precursors to the Canons.

\section{The Duty to Do Justice in Early-Nineteenth-Century Religious Jurisprudence}

David Hoffman and George Sharswood, the authors of the two most important early-nineteenth-century American treatises on legal ethics, approached the field of legal ethics from a tradition this article will refer to as "religious jurisprudence." 19 Their view, based on religious conviction and a belief that a divine intelligence gave human beings moral faculties that would not lead them astray, posited that lawyers could and should exert their sense of justice in individual cases to steer the legal system toward just results.

a. David Hoffman's "Resolutions for Professional Deportment." As Hoffman's biographers have described, his background as a member of a wealthy mercantile family led him to law as a career that would allow him to rise to a more "noble" calling (Bloomfield 1979). ${ }^{20}$ Hoffman used his family's business connections to build a very successful law practice and at the same time undertook a prodigious self-guided course of study of the classics of religious, philosophical, and legal thought. Hoffman proposed to rely on these classics to teach aspiring law students in a seven-year-long curriculum at the University of Maryland. This law school was short-lived, ${ }^{21}$ but

Scholars (e.g., Schneyer 1989, 1984) focusing on the process of drafting legal ethics rules in more contemporary periods have highlighted how disputes and clashes of perspective frequently produced vague or even incoherent final results. My findings suggest that such clashes were prevalent in drafting our earliest legal codes as well.

19. This tradition is sometimes referred to as "natural law," but that term is too broad, since it is frequently also used to encompass forms of legal thought, such as the natural rightsbased formalism of the later nineteenth century, that are entirely different from what I intend to refer to here. For a general historical overview of the natural law tradition, see Weinreb $1987,15-96$. For a discussion of the legal thought of one adherent to this tradition, see Siegel 1995.

20. Many elite professionals in the eighteenth century shared such middle-class backgrounds and were attracted to the ideology of lawyers' professional independence as means of asserting greater prestige (Hurst 1956; Gordon 1988, 16).

21. For a discussion of the abortive movement to establish institutions for classroom law training in the early 1800s, see Hurst 1956, 258. 
Hoffman's "Resolutions for Professional Deportment," which he drafted as part of its curriculum, became a historical classic of lofty legal ethics thought. It is doubtful that Hoffman's "Resolutions" had much influence on the practicing bar of his day; as scholars have noted, Hoffman wrote in reaction against what he perceived to be a debasement of professional standards during the Jacksonian period. ${ }^{22}$ The ABA Ethics Committee nevertheless turned to Hoffman in considering how to express the profession's most noble ambitions.

Hoffman's approach to legal ethics, like his jurisprudence generally, was steeped in religious conviction. Hoffman envisioned human law, human morality, and the laws of nature and the physical world as part of one integrated, divinely inspired system:

Law, in its most comprehensive signification, is that system of rules to which the intellectual and physical worlds are subjected; either by God their creator or by man; by which the existence, rest, motion, and conduct of all created and uncreated entities are regulated, and on the due observance of which their being or happiness depends. (Hoffman [1836] 1972, 55)

Religious jurisprudence distinguished, however, between divine law, the source of a harmonious and universal system of moral rules; and human law, which was fallible and imperfect and thus could only approximate divine morality. The imperfection of law administered by human beings accounted for why unjust results were sometimes obtained under a legal system inspired by God. Human beings, prone to fallibility and error, sometimes made mistakes, and those mistakes produced distortions in the law, causing it to reflect divine morality only imperfectly. Accordingly, to Hoffman's view, proper operation of the legal process mandated lawyers' active moral involvement to ensure just results. The weight of ensuring just results in particular cases rested not only with the judge, but with the other actors in the process as well, especially the lawyers, fellow officers of the court.

Hoffman's view is evident in many of his Resolutions. To take but a few examples, Hoffman's Resolution 11 vows that:

If, after duly examining a case, I am persuaded that my client's claim or defense (as the case may be), cannot, or rather ought not to be sustained, I will promptly advise him to abandon it. To press further in such a case, with the hope of gleaning some advantage by an extorted compromise, would be lending myself to a dishonorable use of legal means.

22. For a discussion of Hoffman's lack of impact on the practicing bar of his day, see Bloomfield 1979. For a discussion of the state legislative attacks on the organized bar during the Jacksonian period, see Chroust 1965, 129-65. 
And, in Resolution 14, Hoffman argues:

In civil cases, if I am satisfied from the evidence that the fact is against my client, he must excuse me if I do not see as he does, and do not press it; and should the principle also be wholly at variance with sound law, it would be dishonorable folly in me to endeavor to incorporate it into the jurisprudence of the country.

Hoffman's Resolutions further vow never to invoke the defense of stat: ute of limitations or infancy against just claims; to refrain from resorting to "ingenuity," "artifices of eloquence," or "appeals to the morbid and fleeting sympathies of weak juries or of temporizing courts" in defending guilty clients in criminal trials; and always to donate a portion of one's services to clients with "just causes" who lacked the means to pay (Hoffman [1836] 1972, Resolutions 12, 13, 15, and 18).

Hoffman, in short, envisioned the lawyer's role as involving a gatekeeping function: a duty to protect the legal system, administered by human beings prone to error and misunderstanding, from the harmful effects of achieving unjust results.

b. Sharwood's Treatise on Legal Ethics. Hoffman's "Resolutions"argumentative, defensive, and more than a little bombastic-were followed two decades later by the more careful and considered legal ethics treatise authored by George Sharswood, a justice of the Supreme Court of Pennsylvania and part-time lecturer in law at the University of Pennsylvania. Sharswood, like Hoffman, wrote his classic legal ethics treatise for use as a text for his students. Sharswood's treatise displayed none of the overweening confidence that marks Hoffman's treatment of lawyers' duties to attend to the justice of their clients' causes, but Sharswood, too, reached much the same conclusion as Hoffman had on this issue.

Sharswood began his discussion of the duty-to-do-justice issue by acknowledging that he could not see any "easy solution" to the dilemmas posed about lawyers' role in achieving justice. Indeed, Sharswood considered the topic of a lawyer's "duty of fidelity to the client," especially where the interests of the client conflicted with the lawyer's "own sense of what is just and right," to raise the "most difficult" question regarding lawyers' professional duties (Sharswood 1860, 76, 81). After rehearsing at length the arguments on both sides of the issue, Sharswood concluded that, from the perspective of an individual lawyer's ethical obligations in particular cases, a lawyer should refuse to represent a party who wished to pursue a claim that offended the lawyer's "sense of justice" (Sharswood 1860, 96). ${ }^{23}$ Sharwood likewise proposed that counsel should "wisely and justly" utilize the discre-

23. Some readers have argued that Sharswood opposed the "duty-to-do-justice" view (Pearce 1992, 256-58), but on my reading, Sharswood recites the arguments on both sides of 
tion granted under the American system to turn down cases, and "may and even ought to refuse to act under instructions from a client to defeat what he believes to be an honest and just claim." Sharswood further proposed that in cases in which the client's cause was "righteous," lawyers would be ethically justified in "refusing to yield any legal vantage-ground" gained by the mistakes or ignorance of opposing counsel. In civil cases in which justice was not wholly on a client's side, on the other hand, lawyers should mitigate their tactics accordingly (Sharswood 1860, 98-99).

By the last quarter of the nineteenth century, the doubts Sharswood acknowledged on the duty-to-do-justice issue had grown into a full-scale "paradigm shift" in legal ethics thinking, at least within the more cosmopolitan sectors of the bar. Influenced by new jurisprudential models that began to replace a religiously motivated jurisprudence, legal ethics thinkers began to endorse the view that justice would emerge as a matter of course from the working of the system, and that the lawyer, as one player in this system, should concern himself solely with playing his role as an advocate in order for this process to work effectively.

\section{Late-Nineteenth-Century Legal Ethics}

The shift in legal ethics thinking about lawyers' duties to monitor the justice of their clients' causes corresponded roughly with the introduction of positivism and scientistic models of the legal system in American jurisprudence. ${ }^{24}$ Whereas Hoffman's and Sharswood's religiously based jurisprudence imbued lawyers with the power-and thus the duty-to preserve the tenuous connection between human affairs and a divinely inspired moral system, the new legal ethics paradigm disavowed any such connection between law and morality. If morality and law were separate, as the positivists claimed, it no longer necessarily followed that lawyers should serve as gatekeepers for the justice of their clients' causes. The influence of natural and social science theories also played a key part in this shift in thinking. To the extent that lawyers began to conceive of the operation of the legal system as dependent on impersonal, invisible laws, there no longer appeared to be a connection between a lawyer's moral qualms about a case and any personal responsibility. To the contrary, the rhetoric of the period began to claim that it was essential to the proper workings of the system that the lawyer

the issue and then comes down unequivocally in favor of recognizing a duty to do justice on the part of individual lawyers in particular cases.

24. For general discussions of the rise of positivism in the late nineteenth century, see Horwitz 1992 and White 1949. For a discussion of the development of social science theory during this period, see Ross 1991; Siegel 1990; Wiebe 1967,140; Gordon 1983, 87-98; 1981; Hurst 1956, 3-32. 
fulfill his role as advocate without concern for his feelings of distaste about apparent instances of injustice. ${ }^{25}$

This shift in perspective is strikingly apparent in the deliberations of the first state bar associations to adopt comprehensive legal ethics codes, starting with Thomas Goode Jones's 1887 adaptation of Sharswood's treatise for use as a legal ethics code in Alabama. ${ }^{26}$ Jones's adaptation made significant modifications on the duty-to-do-justice issue (a fact that seems to have wholly escaped the attention of legal ethics scholars). Far from endorsing Sharswood's views on lawyers' responsibility for justice, Jones's original draft code contained a provision stating:

An attorney may decline in a civil cause to conduct a prosecution, when satisfied that the purpose is merely to harass or injure the opposite party, or to work oppression or wrong: but once entering the cause he is bound to avail himself of all lawful advantages in favor of his client, and cannot without the consent of the client afterwards abandon the cause. (Alabama State Bar Association 1887a, 8, 19; Jones 1922)

25. The masculine pronoun is used advisedly here, since the bar's membership during this period consisted almost exclusively of men. Indeed, a fascinating-though controversial-correlation can possibly be drawn between the rise of these rationalistic, scientistic models and the exclusion of qualities attributed to the "feminine" aspect of human consciousness, such as sentiment and morality. Some commentators have argued that American social science (Ross 1991, 59) and legal thought (Siegel 1995, 239; Menkel-Meadow 1996b) took a "masculine" course in the late nineteenth century in abandoning Scottish enlightenment beliefs that God had given humans trustworthy intuitive moral judgment. Others are skeptical about theories that posit the abandonment of Scottish enlightenment philosophy as a significant factor in changes in nineteenth-century jurisprudence (Gordon 1983).

26. This movement is likewise evident in the legal treatises and professional rhetoric of the period. Examples include Forsyth's treatise arguing that "[c]ases constantly occur-indeed the majority of litigated question are of this nature-in which beforehand it is impossible to say on which side the legal right lies," and that "[i]t would be ... mere tyranny and injustice, if the decisions of courts were to be anticipated by private opinions, and lawyers were to assume that they could divine the verdict or judgment, and consequently refuse, on such grounds, the aid of their professional skill" (Forsyth 1881, 393, 395), and an 1899 article arguing that justice is best produced experimentally in the adversary system, and that lawyers as advocates should not take only those cases in which they believed just because lawyers have "no monopoly in truth-seeking" and no reason to think they will "arrive unaided at a just conclusion as to the law" (Rogers 1899, 259, 264-68). William Harbaugh has similarly documented how prominent lawyer John Davis justified his eviction of family friends from their property early in his practice with explanations that " $[t]$ he lawyer must steel himself like the surgeon to think only of the subject before him \& not of the pain his knife may cause,"' and later expounded that "the lawyer's duty was to represent his client's interest to the limit of the law, not to moralize on the social and economic consequences of his client's actions" (Harbaugh 1973, 46, 264). David Dudley Field used similar arguments in his infamous public debate with a newspaper editor who criticized his representation of the notorious Erie Railroad and its directors James Fisk and Jay Gould, defending his representation by arguing that to say lawyers should not represent "bad men" was "equivalent to saying that the saints must have a monopoly of lawsuits," and that it should not be argued that lawyers "should never engage in the wrong side of a cause," because "in the present condition of humanity facts are often misunderstood, the law often mistaken, and one court frequently pronounces right what another court has pronounced wrong" (Schudson 1997, 191). 
Jones's proposal was defeated when the Alabama State Bar Association's general membership meeting accepted an amendment from the floor that deleted the italicized language quoted above (though that language would receive a second hearing during the drafting of the 1908 Canons, as described further in part IV.A of this article. ${ }^{27}$

In 1889, the Georgia Bar Association adopted, virtually verbatim, the Alabama State Bar Association's legal ethics code (Georgia Bar Association $1889,99)$. Within a decade, however, the Georgia Bar Association's Committee on Legal Ethics convened to consider a question the Alabama code had not clearly resolved, namely, whether a lawyer can "conscientiously advocate one side of a case when he knows that if employed by the opposite party he would have advocated a totally different view" $(1896,218)$. The committee concluded that lawyers should not resolve only to take the right side of a dispute because observance of such a rule would require that "the lawyer should know fully both sides of the case in advance-which is impossible-and that he should usurp the province of the judge and jury" $(1896,219)$. The committee adamantly asserted that "law and morality are distinct" and denounced as "dangerous dogma" notions based on the existence of "higher law." And, the committee argued, even though:

It is no uncommon thing for the bar to witness miscarriages of justice, in particular cases ... [s]o far as these result from the enforcement of law, the lawyer, as such, may witness them and take part in them with perfect complacency. He takes the "wide survey of causes" and realizes [that] ... "some things must be done unjustly in order that more things may be done justly." $(1896,242)^{28}$

Similar ideologies would inspire some of the ABA members active in developing the 1908 Canons. In the words of one author who commented on the Ethics Committee's draft proposals, it was in acting for clients in pursuing the most fundamental "law of nature"-namely, the "struggle for self"-that lawyers could be expected to engage in the most "free and independent thinking" and the "discovery and assertion of moral rights" that

27. In the end, the 1887 Alabama legal ethics code merely provided that "an attorney must decline in a civil cause to conduct a prosecution, when satisfied that the purpose is merely to harass or to injure the opposite party, or to work oppression and wrong" (Alabama State Bar Association 1887b, 111).

28. The committee's report also contained an interesting proposal for how to "cure" the damage to "the souls and intellects of lawyers" that might occur from having to ignore their moral sentiments in fulfilling the duties of their professional role. The recommended remedy was for lawyers to become involved through state bar associations in efforts to reform the legal system. Through such activities, the Georgia Bar Association $(1896,242)$ suggested, the lawyer would again find himself engaged in work in which "truth alone is the object of his direct search," and thus could break from the "mental labors and habits" required by his profession. Gordon $(1984,65)$ has noted and described as "schizoid" this same late-nineteenth-century trend toward focusing on law reform activities as the exclusive forum for lawyers' concern with the justice. 
would lead to the development of "moral law as the law of the land" (Abbot 1913, 81-82). In other words, just as economic markets could be expected to produce the most efficient outcomes when individuals pursued their selfish ends, rules of law could be expected to achieve greater moral perfection as lawyers pursued their clients' selfish ends through the adversarial system.

In sum, the close of the nineteenth century left lawyers with conflicting intellectual paradigms within which to approach the issue of lawyers' duty to evaluate the justice of their clients' causes. The view based on religious jurisprudence still had its adherents, especially among older generations of the bar and those who had been educated by reading the centuriesold law classics (e.g., Wolverton 1900). But legal thought had taken new directions, many of which sought to debunk religious jurisprudence as oldfashioned and unscientific (Siegel 1995, 217).

Given the intellectual histories of the two approaches, one might predict that the older members of the 1908 Ethics Committee would have been most likely to champion an approach based in religious jurisprudence, while the committee members who had reached maturity later in the nineteenth century, after positivism and scientistic models had entered American legal thought, would lean toward the opposite position. In fact, exactly the opposite affiliations occurred, for reasons that will be explored below.

\section{PARTICIPANTS' POSITIONS ON THE DUTY-TO. DO-JUSTICE ISSUE}

As already mentioned, the ABA's 1908 Ethics Committee was composed exclusively of men, all Anglo-Saxon and Protestant so far as the historical evidence reveals, and all part of the social and economic elite of the profession. The biography of each of these 14 committee members is summarized in appendix A, and a statistical profile is presented in appendix B..$^{29}$ This part will highlight the biographies and legal ideologies of some of the key participants in formulating the 1908 Canons whose positions on the duty-to-do-justice issue can be ascertained from the available historical materials.

The debate on the duty-to-do-justice issue within the committee was sparked by the committee's survey of the rules of legal ethics in effect in the states. ${ }^{30}$ The committee determined that some states had adopted "lawyers' oaths," which included language requiring lawyers to swear that "I will

29. As detailed in appendix B, the average age of the Ethics Committee members was 61 years old. The earliest date of bar admission among the group was 1860 , and the latest, 1891 . Approximately $73 \%$ of the committee members had received college educations, as compared to $4 \%$ of the total white male population at the time (Auerbach 1974, 29).

30. Drinker $(1953,23)$ provides a survey of the state codes of ethics in place at the time the ABA Ethics Committee took up its drafting work. 
counsel and maintain such actions, proceedings, and defenses only, as appear to me legal and just; except in the defense of a person charged with a public offense." This language (hereinafter "Lawyers' Oath language") was contained in the codes of 18 midwestern and western states, ${ }^{31}$ but was not part of the codes of the several southern states that had followed the Alabama State Bar approach to professional ethics. ${ }^{32}$ This Lawyers' Oath language thus became a sort of litmus test on the duty-to-do-justice issue. In its first draft of proposed canons, the committee included the Lawyers' Oath language, noting its origins in the lawyers' oaths of a number of states and asking for comment on it. ${ }^{33}$

A second focus for discussion of the duty-to-do-justice issue was in the comments received in response to a question Alexander posed in a cover letter that accompanied his mailing. Alexander asked on behalf of the committee for advice and proposed canons addressing an issue that past legal ethics authorities had not addressed, namely, what principles "should ever guide the lawyer, true to his country, his client, and himself, in accepting the retainers of individuals and of corporations and in representing or advising them ...." 34

Committee Secretary Alexander mailed these queries and draft canons to all members of the ABA and the secretaries of each state bar association (Alexander 1908, 3). Of the more than 1,000 replies received, Alexander compiled the "more important and complete" into a 130-page document. It is this document that provides the best evidence of the committee's division of views on the duty-to-do-justice question.

31. These states were California, Idaho, lowa, Minnesota, Nebraska, North Dakota, Oklahoma, South Dakota, Utah, and Wisconsin (Committee on Code of Professional Ethics 1907, 112).

32. These states were Alabama, Georgia, and Mississippi. There thus appears to have been a distinct regional variation in states' approaches to the duty-to-do justice issue - a variation also reflected in the divergence of views among lawyers from different regions on the same question within the 1908 committee, as discussed further below. Differences in the legal cultures of these various regions may account for the divergence of approaches, though a comprehensive exploration of what those specific differences may have been must await a future project. Haber $(1991,1-70)$ provides a start with his comparative analysis of the nineteenth-century legal cultures of a southern and a midwestern city, in which he concludes that southern lawyers tended to combine law practice with plantation life and business investing and supported a view of lawyering that emphasized independence, while midwestern lawyers were typically more middle class and concentrated more on voluntary association activities.

33. The committee further traced the pedigree of these lawyers' oaths to the centuriesold Swiss canton of Geneva (Committee on Code of Professional Ethics 1906, 676, 714).

34. The omitted continuation of the quotation above stated "knowing that by virtue of the establishment of the relation of counsel and client it will be his duty, within the scope of the retainer, to guard by every honorable means and to the best of his learning and ability the legal rights of the client" (Committee on Code of Professional Ethics 1906, 8 [emphasis in original]). 


\section{A. Supporters of the Duty-to-Do-Justice View}

A seemingly odd coalition of committee members and outside commentators advocated the retention of the Lawyers' Oath language in a national model legal ethics code. This coalition included one of the oldest members of the committee, who espoused a pre-Civil War view of lawyers' independence, and one of the youngest members of the committee, who displayed a moderate Progressive orientation.

\section{Thomas Hamlin Hubbard}

One of the chief advocates of the duty-to-do-justice position on the: committee was Thomas Hamlin Hubbard, a highly successful corporate lawyer in New York City. Hubbard had practiced law in several small New York City law firms and was director and counsel to a host of railway companies, banks, and insurance companies. Displaying a scholarly interest in legal ethics, Hubbard taught a course on the subject at his alma mater, the Albany Law School, and endowed the Hubbard Foundation of Legal Ethics there. Hubbard also published one of the first case books on the subject.

A former general in the Union army, Hubbard was among the oldest members of the committee. He was also one of the strongest advocates of including language in the Canons to emphasize lawyers' ethical accountability for the justice of the causes they filed on behalf of clients. Hubbard proposed that the Canons state that a lawyer:

may counsel and maintain only such actions, proceedings and defenses as appear to him just, except in the defense of a person charged with a public offense: His appearance in court should be deemed equivalent to an assertion, on his honor, that in his opinion his client is justly entitled to some measure of relief refused by his adversary.(Alexander 1908,107 )

On the issue of retainers, Hubbard argued, "every lawyer must decide what business he will accept as counselor, what cases he will bring into court for plaintiffs, what cases he will conduct in court for defendants." By the same token, Hubbard asserted, it was the lawyer's sole responsibility to decide what claims to make on behalf of his clients; a lawyer could not escape this responsibility "by urging, as an excuse, that he is only following his client's instructions" (Alexander 1908, 107).

\section{Ezra Ripley Thayer}

The other chief supporter of the duty-to-do-justice position on the Ethics Committee was Ezra Ripley Thayer of Boston, Massachusetts. At 42 
years old, Thayer was the youngest member of the committee and a moderate Progressive in political orientation. ${ }^{35}$ Thayer had graduated from Harvard College in 1888, from Harvard Law School in 1891, and had served as a secretary to Supreme Court Justice Horace Gray before becoming an associate and then a member of Louis Brandeis's firm, Brandeis, Dunbar, and Nutter (Harvard Law School Association 1916). At the time of his participation on the committee, Thayer had recently left Brandeis's firm to join a new firm organized by Moorfield Storey-Storey, Thorndike, Palmer, $\&$ Thayer-where he served as Storey's chief assistant in litigation (Howe $1932,186)$.

Louis Brandeis and Moorfield Storey, the leading members of the two firms at which Thayer practiced, are, of course, two of the best-known Progressive-Era corporate lawyers who purportedly practiced law by seeking to do justice rather than simply advancing their clients' interests. ${ }^{36}$ The worldviews and approaches to lawyering of these two men were very different, however: Storey was a New England puritan of the same generation and mind-set as Thomas Hamlin Hubbard, ${ }^{37}$ while Brandeis-younger, and an outsider by virtue of his Jewishness - was a brilliant and visionary innovator in his approach to practicing law. ${ }^{38}$ The two men were, in fact, bitter enemies, clashing on the very issue of legal ethics, as historians have already

35. Another moderate Progressive on the committee was Alton Parker, 1907 president of the ABA. Parker had been a state court judge and joined an "av"-rated Wall Street law firm after his unsuccessful 1904 candidacy for president on the Democratic party ticket. His clients ranged from corporations and railroads to labor leader Samuel Gompers (Who Was Who 1966, 934; Rogers 1932, 40-45). Parker's manuscripts on deposit at the Library of Congress unfortunately shed no direct light on his stance in the Ethics Committee debate.

36. For discussion of Moorfield Storey's approach to lawyering, see Howe 1932 and Hixson 1972. Storey's writings on legal ethics include pronouncements that corporate lawyers should serve as guardians of the "deep public interest in which the calling of the lawyer is affected" and that it is lawyers' duty-not the possibly "angry or unscrupulous" client's-to "decid[e] whether or not to carry a case further," which duty the lawyer must carry out as "an officer of the Court, whose duty it is to help in securing justice," rather than as an agent of his client, whose purpose might be "to delay or defeat [justicel" (Storey 1911, 6, 30-33). In his actual practice, however, Storey's conduct cannot be reconciled with his rhetoric. For example, Storey's clients included the notorious United Fruit Company, whom Storey defended against antitrust charges stemming from that corporation's instigation of the Costa Rican government's seizure of a rival company's property and supplies in Panama (American Banana Co. v. United Fruit Co., 213 U.S. 347 [1909]). The ruling Storey eventually won from the Supreme Court held that United Fruit's actions were not cognizable under the Sherman Antitrust Act, "however contrary to the ethical and economic postulates" of that statute, because they were acts of a foreign power and occurred outside United States territory (215 U.S. at 357). Storey later stated in his unpublished autobiography that "[we] did not undertake to advise [United Fruit] on questions of business, only questions of law" (quoted in Howe 1932, 185).

37. For a discussion of the effects of Storey's puritan upbringing on his moral worldview, see Hixon (1972).

38. There is a huge literature on Brandeis's lawyering style, which is well summarized in Spillenger 1996. This literature lauds Brandeis for eschewing traditional law-bound approaches to the solution of legal controversies and instead devising innovative solutions based on his brilliant ability to synthesize complex facts. See, e.g., Mason 1936, 23-51; Strum 1993, $25-32 ; 1984,39,72,103-23$. 
explored. ${ }^{39}$ But both men spoke glowingly of Thayer at the memorial service held after his untimely death in 1915, and Thayer appears to have shared some of both his mentors' views about lawyering. 40

Thayer served as the secretary of the Bar Association of the City of Boston Committee on Grievances, and in this capacity participated in drafting comments for the ABA's Ethics Committee on behalf of the Boston Bar Association. Those comments explicitly linked the question of lawyers' responsibility for evaluating the justice of their clients' causes to lawyers' responsibilities in representing large corporations. The Boston Bar Association argued that:

The practice of the law consists to-day, more than ever before, in advising corporations and others who are engaged in promoting or conducting large business enterprises. These enterprises are often so large that they affect the welfare of large communities and even the welfare of the whole country. It is a scandal to the profession that unscrupulous businessmen can find able lawyers who devise or perfect schemes for evading the law, for imposing on investors, and for working injuries to the public; who assist in the work of improperly influencing legislature and city council; and nevertheless, contrive to maintain a high standing among their brethren. We think it is the duty of the bar to hold to obloquy and contempt lawyers who thus prostitute their calling. (Alexander 1908,123 )

Accordingly, the Boston Bar Association proposed that the Canons state that:

It is quite as wicked, unworthy and dishonorable for a member of the bar to assist a rich and powerful corporation ... in working an injury of any kind to the public or to an individual merely because he had been or wishes to be employed as counsel, as it would be for him to do similar things in his own business and for his own personal benefit. For the

39. Storey opposed Brandeis's nomination to the Supreme Court, claiming that Brandeis had engaged in unethical conduct in failing to disclose the true identity of his client in a case with which Storey was farmiliar (Spillenger 1996, 1494-96). Brandeis faced other allegations of unethical conduct during his confirmation hearings as well, especially of ignoring conflict-ofinterest concerns in some instances in which he represented multiple interests in a single case-a practice Brandeis termed acting as "the lawyer for the situation"-and, in one instance, of testifying in a pro bono capacity for the defeat of legislation he had previously helped draft for a corporate client (Spillenger 1996, 1470-1517; Frank 1965).

40. In 1910, Thayer followed in his father's footsteps to become a professor and dean at Harvard Law School. According to Roscoe Pound, Thayer's successor as dean, Thayer was "not by nature or training inclined to extreme sociological views," but acted as bridge between the "past and present" by introducing new theories and ideas at Harvard while retaining the best of the old traditions (Harvard Law School Association 1916, 3-5).

Thayer's papers (1913) in the Harvard University Archives reflect his moderate Progressive tendencies in numerous ways, as when he counseled students and former students, in long letters of advice he often wrote, about the comparative virtues of public service over private practice. 
duty to be an upright and public-spirited citizen, which rests upon a lawyer even more than on a layman, only increases with the importance of the business in his charge. (Alexander 1908, 123-24)

The Boston Bar Association, in other words, viewed the duty-to-dojustice issue as inextricably connected with the Progressive Era preoccupation with curbing the power of large corporations.

\section{George Costigan}

A third outspoken advocate of the duty-to-do-justice view was George Costigan, dean of the University of Nebraska Law School. Costigan was not a member of the 1908 Ethics Committee, but had written a law journal article quoted in the committee's compilation of comments. Costigan argued that:

It is the verist sophistry to attempt the justification which some men do, that every man, be he in the right or in the wrong, has a right to be heard in court. The suitor in an unjust cause of the defender who sets up an unjust defense may have a legal right, but he certainly has no moral right to be heard in court; and since a lawyer, as an officer of courts of justice, is bound to aid in securing just decisions, he has no moral right to assist in securing unjust ones. (Alexander 1908, 99)

Costigan had been a few years behind Thayer at Harvard College and Harvard Law School and had served as a professor and/or dean at several western and midwestern law schools. Costigan published several casebooks, including one of the first major casebooks on legal ethies (Costigan 1917).

\section{Others}

Several other committee members, including Jacob Dickinson, a Chicago railroad lawyer, and outside commentator William Lewis, the dean of the law department at the University of Pennsylvania, supported including the Lawyers' Oath, but provided no explanation for their views (Alexander 1908, 99). Dickinson, a former ABA president, had been active in the codification movement of the late 1800 s (Dickinson 1884). William Draper Lewis was active in the movement to tighten admission standards for law schools and the bar and was one of the earliest academics to explore the application of new social science methodologies to the study of law. ${ }^{41}$ 


\section{B. Opponents of the Duty-to-Do-Justice Position}

Although, as we have already seen, the Ethics Committee's internal debate about the duty-to-do-justice issue became intertwined with participants' views on corporate law practice, participants did not take sides on the issue based on their practice settings. For example, lawyers with corporate law practices, such as Thayer and Hubbard, supported the duty-to-do-justice position, while the most outspoken opponent of this position, William Wirt Howe of New Orleans, was not a corporate law practitioner at all but, instead, had devoted virtually his entire legal career to government service. Howe, a transplanted Northerner from a long line of New England stock; had served as an officer in the Union army and settled in New Orleans after the war, quickly winning appointment as a criminal court judge by the military government then in place there (Rogers 1932, 95-97). Howe eventually became a justice of the Supreme Court of Louisiana and later served as a United States attorney (see appendix B).

Howe bore the distinction of being the oldest member of the ABA's Ethics Committee. Unlike his age-cohort General Hubbard, however, Howe had no use for the duty-to-do-justice position or the attack on corporate law practitioners with which it had become intertwined. In his comments to the committee, Howe lambasted the practice among politicians and journalists of the day "to scold at what they call 'corporation lawyers"' (Alexander $1908,122)$. Howe argued that "the fact that . . statutes [challenged by corporate lawyers on behalf of corporate clients] have been frequently found to be unconstitutional is a sufficient answer to the slur on corporation lawyers," and proposed that "a code of Professional Ethics might recognize the fact that, the more numerous and important corporations become, the more it is the right and duty of the American lawyer to give them advice and to defend them against illegal attack." 42

Turning to the question of the Lawyers' Oath language, Howe repeated the pragmatic arguments of the Georgia Bar Association, arguing that there are "so many instances where counsel differ as to the law of the case, and the true rule can only be discovered when the court has announced its opinion" (Alexander 1908, 101; see also Howe 1907, 518). Howe further argued that it "seems plain and it might be stated that counsel have a right to prosecute or defend a civil suit subject, of course, to [the rule that] they must not misstate fact or misquote law but . . they have the right to apply the law to those facts on behalf of their client with such abilities as they may possess" $(1907,519)$. Howe likened litigation to "a kind of warfare. . . . We are to make war for our clients, but we are to do so in only honorable ways [by stating the facts and law correctly]" $(1907,519)$. When a lawyer

42. Howe developed these same arguments in a contemporaneously published law review article (1899). 
behaved according to these "rules for honorable warfare" in litigation, Howe asserted, "he may then cheerfully leave the result to the general rules which society has made for itself in these matters" $(1907,519)$.

Finally, Howe argued, although cases "will go wrong now and then" and there "may be great miscarriages of justice," this was not the fault of the "rule I have ventured to formulate" but instead the result of inalterable rules of the physical world-just as the "law of gravitation may seem to work badly sometimes, as when the bread-winner of a family falls and fractures his skull" $(1907,519)$.

Howe's views were supported by Washington, D.C., practitioner L. T. Michener, an outside commentator. ${ }^{43}$ Citing Sharswood, Michener submitted this language for a proposed canon:

The client has the right to have his case decided upon the law and the evidence, and to have every view presented to the mind of the judge which can legitimately bear upon the question. The lawyer who refuses his professional assistance because in his judgment the case is unjust and indefensible, usurps the functions of both judge and jury. (Alexan$\operatorname{der} 1908,102)$

The historical record does not reflect with certainty who else supported Howe within the committee. A "prominent" judge, who submitted comments under condition of anonymity, questioned the Lawyers' Oath language, querying, is it "plain, even that [this portion of the oath] is correct? May a man not argue what he thinks is not the law to a Court? He may be wrong-and to decide is the Court's job" $(1908,45)$. Other members of the committee must have agreed with this view as well, since, as discussed in part four of this article, the committee's final draft of proposed canons evinced movement toward Howe's position.

Some suppositions about other committee members' positions can be drawn from historical evidence separate from the committee's records. It surely is no coincidence, for example, that the language Thomas Goode Jones had proposed to the Alabama State Bar Association in 1887, which rejected the duty-to-do-justice position, appeared in the final draft of the ABA Ethics Committee's Canons exactly as Jones had proposed it several decades before.

Supreme Court Justice David Josiah Brewer stands as another committee member who most likely opposed the duty-to-do-justice position. ${ }^{44}$

43. Michener had been attorney general of Indiana, and advertised himself in Hubbell's Law Directory (1908, app. 39) as a member of a two-person general practice firm appearing before courts, government agencies, and congressional committees.

44. Brewer read law in the offices of his uncle; attended Albany Law School for one year, receiving his diploma in 1858; then struck out for Kansas, where he won appointment to the county court when he was 25 years old; and then moved on to various higher courts, 
Brewer, remembered today as a member of the conservative, probusiness, and individual property rights Fuller Supreme Court (Paul 1965, 70-72), was a frequent public speaker on legal ethics and other subjects, and left behind a body of speeches long on platitudes and short on substantive content. His published commentary on legal ethics manages always to skirt taking a real position on the duty-to-do-justice issue (Brewer 1904a, 1904b), but dicta in one of his court opinions suggests that he favored a strongly client-centered approach (United States v. Costen, 38 F. 24 [C.C.D. Colo. 1889]). 45

\section{Middle of the Roaders}

The sections above have described the participants who favored and opposed the duty-to-do-justice position. Two other members of the committee, Henry St. George Tucker and Francis Lynde Stetson, appear to have espoused intermediate views on the issue. Henry St. George Tucker was a past president of the ABA and the chair of the committee. He had been a law professor and dean at Washington and Lee, following in the footsteps of several generations of Tuckers before him. ${ }^{46}$ Stetson is today remembered as a founding member of one of the first large "law factories" that appeared in the late 1800s (Hobson 1984, 8) and as a pathbreaker in developing the specialty of counseling large corporations in complex matters such as corporate reorganizations (Who Was Who 1966, 1180; Hurst 1950, 298; Hobson $1984,8) .47$ Given the stature of these two men within the bar and on the committee, they may well have been influential in bringing the committee to the compromise position it eventually adopted in the final draft of its proposed canons.

Although the documentary record is silent about what these two individuals advocated during the Ethics Committee's internal deliberations on

culminating in his appointment to the U.S. Supreme Court in 1889 (Brodhead 1994, 2, 4, 6 8).

45. In Costen, Brewer wrote, "I can tolerate a great many things that a lawyer may dothings that in and of themselves may perhaps be criticized or condemned when done in obedience to the interest or supposed interest of his client,... If he goes beyond, perhaps the limits of propriety, I can tolerate and pass that by; but I cannot tolerate for a moment, neither can the profession, neither can the community, any disloyalty on the part of a lawyer to his client" (38 F. 24, 24). For a listing of some of Brewer's published opinions on legal ethics questions, see Brodhead $(1994,69)$.

46. Tucker's father was John Randolph Tucker, founder and dean of the Washington and Lee Law School. Henry St. George Tucker started his legal career in a country law prac. tice but soon followed in his father's footsteps in winning election to his father's congressional seat and then becoming law professor and dean at Washington and Lee (Rogers 1932, 135).

47. Stetson's clients included J. P. Morgan; a number of railway companies, including the Erie; the U.S. Rubber Company; the International Mercantile Marine Company; and the International Paper Company. His legal work created some of the most massive corporate conglomerations of his time, including the U.S. Steel Corporation and International Harvester (Harbaugh 1973, 186). 
the duty-to-do-justice issue, their positions on the question can be gleaned from their contemporaneous writings. Tucker, like his father before him, sought to instill the principles of religious jurisprudence in his law students. ${ }^{48}$ Tucker's views on legal ethics likewise took this jurisprudential orientation as their starting point, albeit with a cast very different from his early-nineteenth-century forerunners. In an address before Hubbard's legal ethics class at Albany Law School, Tucker attributed the lay public's disapproval of lawyers' behavior to its ignorance of the distinction between divine law (jus) and human law (lex) and its failure to appreciate that lawyers' practice was "before a human judge, upholding human law," which "necessarily cannot be perfect" (Tucker 1911b, 110). Thus, Tucker's jurisprudence, like Hoffman's and Sharswood's, distinguished between divine law, the source of a harmonious and universal system of moral rules, and human law, which was fallible and imperfect and thus could only approximate divine morality. But Tucker focused on this distinction to excuse (rather than condemn, as Hoffman would have) lawyer behavior the lay public found objectionable.

Tucker's early-twentieth-century version of religious jurisprudence likewise did not adhere to Hoffman's and Sharswood's analysis on the dutyto-do-justice issue. Tucker $(1911 \mathrm{~b}, 113)$ proposed in a speech delivered shortly after the 1908 Canons were adopted that a lawyer should be free to advise corporate clients on how to avoid legal regulation, unless "the method which he suggests to his client ... will, in his judgment, create an instrumentality hurtful to the state of which he is a citizen, or to the development of his country in the paths of freedom, liberty, and progress." Tucker further proposed that a lawyer who thought that the aggregation of corporations into giant trusts was harmful to society "would not be justified in advising his client to evade the [antitrust] law that was obstructing him, if the end to be accomplished, in his opinion, is against the public good." But, Tucker suggested, "it is perfectly consistent in another lawyer to give the advice which would accomplish the same ends for the client, if he believes the object a good one" (1911b, 113). Tucker thus argued for a transformation of the positive duty to monitor the justice of clients' causes into a negative dury to avoid doing injustice. He sought, in other words, to reconcile his moral sense that lawyers should do no harm to their society with his awareness that many elite lawyers of his generation pursued the interests of

48. Tucker (1844) began his series of introductory lectures to his law students by explaining that "rules of rectitude prescribed to us by the author of our being and pointed out by our reason" are "the source from which all human laws derive their validity and value." Later, Tucker taught at both University of Virginia and the Columbian (now George Washington University) School of Law in Washington, D.C., and authored many conservative legal treatises, including an opposition to women's suffrage by constitutional amendment (Who Was Who 1966; Tucker 1916). 
their powerful clients regardless of the social consequences of their representations. ${ }^{49}$

Similarly, corporate counselor Stetson spoke in a vocabulary that sounded like religious jurisprudence but arrived at conclusions that do not correspond with the duty-to-do-justice view. Unlike some of his colleagues who argued that lawyers' choice of clients was morally neutral, ${ }^{50}$ Stetson was an unabashed defender of the moral virtues of representing corporations. Writing in a popular law magazine, Stetson proposed that corporate lawyers had a duty, as "advocate[s] of individualistic liberty," to seek "to assert individual rights in and through any and every way not barred by statute," and even to oppose and possibly counsel noncompliance with "invalid" laws, just as the abolitionists once had in opposing laws upholding slavery (Stetson 1909, 50). Thus, Stetson, like Tucker, held views about lawyers' roles in promoting justice somewhere in the middle of those who favored and those who opposed the duty-to-do-justice position. Stetson believed in lawyers' duty to do justice, but viewed this duty as best carried out by aggressively championing the liberty rights of corporations.

\section{Variables Accounting for the Committee Members' Diverging Views}

As the preceding sections make clear, the committee members' positions on the duty-to-do-justice issue did not break cleanly along the lines that might be expected. The Progressive Era preoccupation with lawyers' proper role in representing powerful corporations figured explicitly in the debate, but the sides to the debate did not line up according to types of practice: Some corporate lawyers, such as Hubbard and Thayer, supported the inclusion of the Lawyers' Oath language, while Howe, the chief defender of corporate law practice, had devoted his legal career to government service. Nor did the participants in the debate break along generational lines: Hubbard and Howe, the two oldest committee members, were also the most divergent in their views.

Regional allegiances, on the other hand, do appear to have some explanatory weight. It is surely not insignificant that the strongest views against the prevailing methods of corporate law practice were offered by the Boston Bar Association, whose members were witnessing the eclipse of small-scale law practice in Boston by the corporate "law factories" of New York City. The committee's debate about the duty-to-do-justice issue thus appears to reflect reactions to the changing structural conditions of legal

49. In other writing, Tucker (1911a) criticized corporations for being no more "law abiding" in challenging the constitutionality of states' attempts to regulate them than were states in passing legislation stuck down on constitutional grounds by the Supreme Court.

50. See supra note 26 . 
practice and the concomitant Progressive Era preoccupation about the growing power of corporations and the threat these organizational giants posed to lawyers' professional independence. Regional divisions may also be evident in the similarities between the positions taken in the committee's debate by Howe of Louisiana and Michener of Washington, D.C., and the approach taken by the Georgia State Bar Association a decade earlier. ${ }^{51}$

Participants' educational backgrounds and continuing ties to legal academia also appear to have some significance: the chief proponents of the duty-to-do-justice position-Hubbard, Thayer, and Costigan-had all received liberal arts undergraduate educations and held law degrees, whereas opponents Howe and Michener do not appear to have held degrees from either college or law school, and thus presumably became members of the bar after reading law in a practitioner's office, which remained the most common avenue of entry into the profession during their generation (Haber 1991, 221-22).

The committee's division on the duty-to-do-justice question thus may reflect the split between the practicing bar and legal academy that was beginning to widen during the period in which the committee was debating the Canons. As a number of legal historians have documented (e.g., Auerbach 1971), the beginning of the twentieth century saw law professors working to define themselves as a new breed of legal specialists with an agenda and values distinct from those of the practicing bar. This new breed of law professors was not nearly as specialized or removed from practice as are the law professors of today. But the move toward specialization and detachment from practice is clearly apparent in the writings of men such as commentator William Lewis (1900, 1913), and in Thayer's (1911) future academic writing as well.

It was these professors, in alliance with the small elite from the practicing generation of lawyers who had received law school educations, who led the campaign for higher standards for legal education and bar admissions (Stevens 1983, 454; Auerbach 1971; Schlegel 1985; Johnson 1978). These professors also began to sound out the ideas that would develop into the sociological jurisprudence movement of the 1910s and 1920s. Their intellectual commitments reflect the transition between the legal science of the late nineteenth century and the nascent school of sociological jurisprudence, which emerged in full bloom a few years after the ABA's Ethics Committee drafted the Canons. ${ }^{52}$

These Progressive Era thinkers lacked our present-day conceptions that different interest groups may have irreconcilable social policy objectives. To men such as Ezra Ripley Thayer and William Draper Lewis, social science

51. See supra part II.B.2.

52. For general discussions of the rise of the sociological jurisprudence movement, see White 1978; Johnson 1981, 129; Gordon 1983, 95; Horwitz 1992, 18. 
analysis would definitively reveal which social policies would best advance the public interest, and law students trained in policy analysis would enter practice with a new ability to identify the best solutions to legal disputes from a policy perspective. ${ }^{53}$ This general jurisprudential agenda may explain why the more academically oriented commentators supported the duty-todo-justice view. That view of lawyers' role fit neatly into their Progressive Era optimism that they, as legal experts with a new policy expertise gained from the use of social science methodologies, could and should determine the "best" solutions to legal disputes.

Conversely, a number of the practitioners among the committee's membership had learned law through the apprenticeship system that the legal professors disparaged. Significantly, some of these committee members were most hostile to the universalistic legal ethics model the law professors endorsed (see apps. A and B). Implicit in the objections of these opponents of the duty-to-do-justice view was a skeptical pragmatism perhaps borne of their own formative life experiences. Steeped in the world of practice, these men doubted that the correct outcomes of legal disputes could be determined by ex ante analysis.

In short, a number of fundamental structural tensions within the profession are obvious in the committee members' positions on the duty-to-dojustice issue. The committee did not confront these disagreements head on, however; it instead adopted some of the language proposed by both groups and modified the Lawyers' Oath language to espouse a negative duty to avoid injustice, much like the position committee chair Henry St. George Tucker advocated in a public address (Tucker 1911b). These compromises in the committee's final draft of the 1908 Canons are outlined below.

53. As one colleague described Thayer's perspective, "Law schools, he thought, should in some degree perform for the science of law what the medical schools in their laboratories perform for the science of medicine, constantly providing new data and suggesting new hypotheses, which practitioners and judges might put to the test in their daily labors" (Harvard Law School Association 1916,6). Defining his assumptions about the nature of law, William Draper Lewis $(1913,536)$ argued:

If law is a form of expression of a social ideal and one of the necessary functions of the courts is to mold the law . . to meet the changes in social ideas as they occur, it is manifest that social science, and especially that branch of it which deals with group development and the growth of social ideas[,] is a necessary part of legal education. Indeed, if we admit that law is the expression of social ideas[,] the study of forces by which those ideas are developed and changed is necessary to a thorough grasp of the development of the law, and being so necessary may be regarded as an essential basis of a thorough legal training.

As early as 1900 , Lewis argued $(1900,640-41)$ that the proper preparatory study for law students required not only a college degree (an idea that would greatly restrict access to the profession, since only a small portion of even the white male population held college degrees [Auerbach 1974, 29]), but also a college education with a specific substantive focus-not on the reading of literary and philosophical classics, the literary diet of early legal ethics thinkers such as Hoffman and Sharswood-but instead on the social sciences-specifically, economics, history, and sociology. 


\section{THE COMMITTEE'S RESOLUTION OF THE DUTY. TO-DO-JUSTICE ISSUE}

After circulating its compilation of state ethics codes and commentary discussed above, the Ethics Committee prepared and circulated a preliminary draft of its proposed canons. This draft reportedly was "overwhelmingly approved" by commentators (except on the thorny issue of contingency fees), 54 and was in turn unanimously approved by the Ethics Committee members (Committee on Code of Professional Ethics 1907, 107). Although we cannot know precisely what took place in these final committee deliberations, the differences between the 1907 draft submitted to the committee and the final 1908 draft reported out of committee provide telling clues.

\section{A. The Ethics Committee's Final Draft and Report}

The results of the Ethics Committee's internal deliberations on lawyers' duties to monitor the justice of their clients' causes are evident in several provisions of its final 1908 draft. That draft contained a code, which generally tracked the language of the Alabama Code, and an oath, modeled after the Lawyers' Oath, which had included the provision sparking the debate discussed above. Both the draft code and the oath proposed in the Ethics Committee's 1908 draft, however, contained significant modifications on the issue of lawyers' duty to evaluate the justice of their clients' claims. In each instance, the changes evinced the committee's movement away from the view that lawyers should be held to have such ethical duties.

In several of its provisions, the 1908 draft Canons reflected a move away from the view that lawyers should be held ethically responsible for the justice of claims they pursued for their clients. First, Canon 30 greatly weakened Hubbard's proposed language that a "lawyer's appearance in court should be deemed equivalent to an assertion, on his honor, that in his opinion his client is justly entitled to some measure of relief refused by his adversary." The revised statement asserted simply that a lawyer's "appearance in Court should be deemed equivalent to an assertion on his honor that in his opinion his client's case is one proper for judicial determination" (Committee on Code of Professional Ethics 1908, 583 [emphasis added]). ${ }^{55}$

54. For the floor debate on the contingency fee issue, see American Bar Association (1908, 61-85). For one analysis of this debate, see Auerbach (1974, 45-51).

55. Canon 31 retained some of Hubbard's proposed language:

No lawyer is obliged to act either as adviser or advocate for every person who may wish to become his client. He has the right to decline employment. Every lawyer upon his own responsibility must decide what business he will accept as counsel, what causes he will bring into Court for plaintiffs, what cases he will contest in Court for defendants. The responsibility for advising questionable transactions, for bringing questionable suits, for urging questionable defenses, is the lawyer's responsibility. He cannot escape it by 
In addition, Model Canon 15, titled "How Far a Lawyer May Go in Supporting a Client's Cause," which had been modeled on the Alabama Code's Section 10 with substantially the same title, was altered to delete the reference in the Alabama Code to the attorney's "accountability to his Creator" and "obligation to his neighbor." The Ethics Committee added new language, tracking the language Thomas Goode Jones had unsuccessfully proposed to the Alabama Legal Ethics Committee stating that in the "judicial forum the client is entitled to the benefit of any and every remedy and defense that is authorized by the law of the land, and he may expect his lawyer to assert every such remedy or defense." With this change, lawyers explicitly were not the guardians of the "justness" of the claims their clients wished to assert. Instead, the lawyer's recognized duty was to assert "any and every" claim cognizable under law.

Finally, the committee redrafted the language of the Lawyer's Oath so that, instead of swearing that "I will counsel and maintain such actions, proceedings, and defenses only, as appear to me legal and just," the committee's 1908 draft provided that "I will not counsel or maintain any suit or proceeding which shall appear to me to be unjust, nor any defense except such as I believe to be honestly debatable under the law of the land" (emphasis added).

According to ABA founder Simeon Baldwin's account of the history of the Canons $(1908,545)$, published shortly after their adoption, the Ethics Committee decided that the original Lawyers' Oath provisions were "subject to serious criticism in that they contained a pledge to counsel or maintain such proceedings only as should appear to affiant to be just." The ABA therefore decided to give this requirement a "different turn," so that lawyers would be required to pledge only that they would not maintain a suit or proceeding that appeared unjust - "an obligation much less onerous." 56

In other, more general language in the 1908 Canons, the committee's rhetoric sounded in tones more harmonious to the duty-to-do-justice position. Along with the language in Canon 15 just discussed, which required lawyers to assert "any and every remedy or defense that is authorized by the law of the land," the committee included an introduction denouncing the

urging as an excuse that he is only following his client's instructions. (Committee on Code of Professional Ethics 1908, 583-84).

This language thus preserved lawyers' discretion and responsibility in choosing clients and deciding how far to go on their behalf, but fell considerably short of endorsing the position that lawyers should make such decisions based on the justice of their clients' causes.

56. Baldwin $(1908,545-46)$ argued that this modification was correct, since if a lawyer had satisfied himself that a case was not unjust in accepting a retainer, "the question becomes one that ought to be decided by a court, after hearing both sides." Baldwin $(1903,27,38)$ had similarly espoused a view opposed to the duty-to-do-justice notion in earlier writings, arguing that "the lawyer's standard-that of honor-is not maintained unless he does for his client whatever that client asks within his legal rights." As an influential outside commentator to the committee, Baldwin probably voiced the same sentiments and contributed to compromise about which he later reported. 
"false claim, often set up by the unscrupulous in defense of questionable transactions, that it is the duty of the lawyer to do whatever may enable him to succeed in winning his client's cause" (Committee on Code of Legal Ethics 1908, 579). The committee also included in its final Canon, entitled "The Lawyer's Duty in Its Last Analysis," an admonishment that a lawyer "advances the honor of his profession and the best interests of his client when he renders service or gives advice tending to impress upon the client and his undertaking exact compliance with the strictest principles of moral law" (1908, 584, Canon 32). These broad pronouncements, in conjunction with the more specific directives discussed above, lent an overall tenor of ambivalence to the text of the 1908 Canons.

The committee presented its final version of its draft canons to the full membership of the ABA in 1908, explaining that it had made modifications to the Lawyers' Oath that were "too abstruse to discuss within the limits of this report" (Committee on Code of Professional Ethics $(1908,572)$. With the exception of the proposed provision on contingency fees, ${ }^{57}$ the entire draft passed without modification and with little debate on the floor of the 1908 annual meeting (American Bar Association 1908, 61-85).

In the aftermath of the ABA's ratification of the canons, state bar associations quickly began to adopt similar ethics codes. ${ }^{58}$ Commentators continued to argue about the duty-to-do-justice issue, sometimes with direct references to the Ethics Committee's debate (Costigan 1917; Oakes 1911; Sims 1925). ${ }^{59}$ Over time, however, references to that debate dropped out of this discourse, and commentators continued to debate the question without any appreciation for what ground the drafters of the 1908 Canons had already covered.

\section{B. Implications for Today's Debate}

In sum, as previously discussed, the canons in their specifics moved away from espousing a lawyers' duty to monitoring the justice of their clients' causes, though they did not, in their more general admonishments, abandon that consideration altogether. It is this ambivalent legacy, arising from the compromise the ABA's Ethics Committee fashioned among the conflicting jurisprudential outlooks of its members, that legal ethics scholars confront when seeking to analyze our inherited legal ethics norms. Moreover, the 1908 Ethics Committee failed to give a candid account of its inter-

57. See supra note 54 .

58. The Illinois Bar Association (1909, § 3), for example, adopted canons stating that a lawyer's "appearance in court should be deemed equivalent to an assertion on his honor that in his opinion his client's case is one proper for judicial determination."

59. Indeed, the Committee on Professional Ethics (1918) reproposed the language of the Washington oath. 
nal debate and downplayed its significance by attributing its modifications from earlier drafts of its proposed Canons to considerations "too abstruse to discuss." 60 In so doing, the Ethics Committee did a disservice to those who would later struggle with the questions the Ethics Committee considered.

The internal working documents of the committee that I have analyzed here reveal that, despite the committee's homogeneity, viewpoints on the duty-to-do-justice issue were surprisingly diverse. The standard assumption that the development of our legal ethics rules proceeded in a relatively harmonious fashion until our present more contentious period thus bears reexamination. Moreover, scholars have been incorrect in assuming that the nineteenth-century precedents that the 1908 Ethics Committee studied in preparing to draft the canons spoke with a uniform voice. A careful analysis of these precedents shows that on the issue of lawyers' duty to do justice, at least, they pointed in contradictory directions, as discussed in part II.B.

This raises yet another implication flowing from the analysis presented in this article-namely, that, again contrary to standard assumptions, the approach the 1908 Ethics Committee took on the duty-to-do-justice issue was not preordained by tradition or precedent, but was open for the committee's conscious choice. The committee explicitly considered and deliberately fashioned its own solution to the issue. Although the members drew on the vocabularies of nineteenth-century legal ethics paradigms, they tailored those paradigms to fit the changing conditions of law practice they perceived as members of the elite bar during the Progressive Era.

Finally, I have attempted to show that the committee members' worldviews and jurisprudential orientations influenced their positions on the duty-to-do-justice issue, but not in the predictable or straightforward ways that might be assumed without detailed empirical inquiry. Instead, each committee member transformed the inherited ideas that accorded with his basic jurisprudential orientation to fit his contemporary preoccupations about how law should be practiced. Thayer and the Boston Bar Association embraced the Lawyers' Oath derived from religious jurisprudence to promote a forward-looking Progressive agenda; Tucker used the vocabulary of religious jurisprudence but modified its duty-to-do-justice doctrine to fit with the practices he observed among his peer group of elite corporate lawyers. Put otherwise, ideas were important to how various committee members came out on the duty-to-do-justice question, but those ideas proved tremendously malleable.

In our contemporary context, it seems worthwhile to reflect on these matters in thinking about how to go forward on the contemporary duty-todo-justice debate. Our current legal ethics rules are no more the result of a

60. Indeed, the document reflecting the committee members' positions is stamped as "STRICTLY CONFIDENTIAL, Unless Bar of Privacy is Removed by the Committee," perhaps contributing to its disappearance from the remembered history of the 1908 Canons. 
coherent progression of ever-improving understandings of the "best" rules for the profession than were the 1908 Canons: In both historical periods, the rules reflect a number of "fragmentary conceptions of the lawyer's role vying conclusively for dominance" (Schneyer 1984, 1569). Just as in 1908, tradition need not, and indeed cannot, dictate how we should think about the duty-to-do-justice question. Instead, informed by an understanding of our legal ethics traditions as reflecting a patchwork of competing visions and conceptions, full of ambivalent and sometimes incoherent compromises, we can and should mold new approaches that take into account our changed practice conditions and contemporary jurisprudential preoccupations, even as we look to the past for greater understanding of how we arrived at where we are today. ${ }^{61}$

\section{CONCLUSION}

This article has attempted to show höw participants' conflicting positions in the internal debates about the drafting of the 1908 Canons grew in unpredictable and transformative ways out of their social and economic milieu and diverse trends in legal thought at the turn of the twentieth century. All the participants in the debate analyzed here shared a common background as members of the bar's so-called elite, defined on lines of religion, race, gender, and socioeconomic class. But within this elite, another differentiation was in progress: that between the practicing bar and a new breed of academic specialists. These new academics and their Progressive allies claimed to possess special insights through social science analysis into the best outcomes for legal disputes. On the other hand, those practitioners with different ideological and jurisprudential commitments opposed the notion that lawyers' ethical duties should include a responsibility to monitor the justice of their clients' causes. The committee's inability to resolve these disputes led it to an ambivalent compromise, in which it merely concealed its internal division and left future generations of lawyers to debate the issue anew, without any awareness of what ground had already been plowed by the 1908 committee.

61. Recent leading work of this type includes Menkel-Meadow 1996a, Wilkins 1998, and Simon 1998. 


\section{APPENDIX A: BIOGRAPHIES OF MEMBERS OF COMMITTEE ON CODE OF PROFESSIONAL ETHICS}

Name: Lucien Hugh Alexander

Year/Place OF BirTH: 1866, Pennsylvania

Education: Harvard College, University of Pennsylvania, B.A. 1888

Year/STATE OF BAR ADMISSION: 1896, Pennsylvania

CAREer HIGHLights: Member of Alexander and Magill, an av-rated general practice firm in Philadelphia; member of board controlling admissions to the Philadelphia bar

SOURCES: Pennsylvania Bar Association 1926, 49; Martindale Hubbell Law Directory 1905

\section{NAME: David Josiah Brewer}

Year/Place OF BIRTH: 1837, Smyrna, Greece (where his father was a missionary)

Education: Wesleyan College, A.B., Yale College, 1856; Albany Law School, LL.B., 1858

Year/STATE OF BAR ADMISSION: 1858, New York

Career highlights: Judge, Kansas county, criminal, and probate court, state district court, federal circuit court, justice of Supreme Court of Kansas; U.S. Supreme Court; taught course at Columbian (now George Washington University) Law School

Religious affiliation: Cöngregationalist

SOURCES: Brodhead 1994; Who Was Who 1966

NAME: Frederick V. Brown

HoME: Minneapolis, Minnesota

NO FURTHER INFORMATION FOUND

\section{NAME: Jacob M. Dickinson}

Year/Place OF BirTh: 1851, Columbus, Mississippi

EdUCATION: A.B., University of Nashville, 1871; studied law at Columbia College, N.Y., and University of Leipzig

YeAR/STATE OF BAR ADMISSION: 1874 , Tennessee

CAREER HIGHLIGHTS: Served in Confederate army before college; practiced law in Nashville and Chicago; assistant U.S. attorney; general counsel for U.S. before Alaskan Boundary Tribunal; attorney for Louisville \& Nashville R.R. Co.; general solicitor and general counsel to Illinois Central R.R. Co.; Secretary of War under President Taft; taught at Vanderbilt University law school; president of the ABA (1907-8)

SOURCES: Who Was Who 1966, 322; Rogers 1932, 146-48; Obituary, New York Times, 14 Dec. 1928, 29, col. 1.

NAME: Franklin Ferris

Year/Place Of Birth: 1849, Peru, New York 
Education: B.S., Cornell, 1873; student, St. Louis Law School, 1875 Year/State of Bar ADMISSION: 1875 , Missouri

Career highlights: Practiced law in St. Louis; member, St. Louis City Council; judge, Eighth Judicial Circuit, Missouri; general counsel, Louisiana Purchase Expedition Company; member, law firm of Ferris, Zumbalen \& Ferris; associate justice, Supreme Court of Montana

SOURCES: Who Was Who 1966, 394; Martindale Hubbell Law Directory (1905)

\section{NAME: William Wirt Howe}

Year/Place OF BiRTh: 1833, New York

EduCATION: A.B., Hamilton College, 1853; studied law in St. Louis

Year/STATE OF BAR ADMISSION: 1855, Missouri

Career Highlights: Major in Union army; law practice in New Orleans; judge, New Orleans criminal court; associate Louisiana Supreme Court justice; U.S. attorney, Eastern District of Louisiana; president, American Bar Association (1897-98)

Religious Affiliation: Episcopalian

Sources: Who Was Who 1966, 596; Rogers 1932, 95; 34 Reports of American Bar Association 1909, 622

\section{NAME: Thomas Hamlin Hubbard}

Year/Place OF BIRTH: 1838, Maine

Education: A.B., Bowdoin, 1857; LL.B., Albany Law School, 1861

YeAr/STATE OF BAR ADMISSION: 1860, Maine

Career highlights: Officer in Union army; member, Butler, Stillman \& Hubbard, New York City; president, Mexican Int'l R.R. Co., Houston \& Texas Central R.R. Co., Guatemala Central R.R. Co., Int'l Bank, Int'l Central R.R. Co.; director, National Bank of Commerce, Toledo, St. Louis \& Western R.R. Co., American Light \& Traction Co., Wabash R.R. Co., Western Union Telegraph Co., Met Life Ins. Co. and others; taught legal ethics and endowed chair for study of legal ethics at Albany Law School

SOurCEs: Who Was Who 1966, 600; Obituary, New York Times, 20 May 1915,11 , col. 5

\section{NAME: James Graham Jenkins}

YeAR/PlACE OF BIRTH: 1834, Saratoga Springs, New York

EDUCATION: liberal education in New York

YeAR/STATE OF BAR ADMISSION: 1855, New York

Career highlights: City attorney, Milwaukee, Wisconsin; unsuccessful Democratic candidate for governor of Wisconsin; judge, U.S. district court, Seventh Circuit Court of Appeals; dean, Marquette University College of Law

Sources: Who Was Who 1966, 632; Current Topics and Notes 1917, 752; Obituary, New York Times, 7 Aug. 1921, 22, col. 5 
NAME: Thomas Goode Jones

Year/Place OF BIRTH: 1844 , Georgia

EDUCATION: Virginia Military Institute, 1862

YEAR/STATE OF BAR ADMISSION: 1868, Alabama

Career Highlights: Served in Confederate army; law practice in Montgomery, Alabama; reporter of decisions of Supreme Court of Alabama; member, Alabama legislature; Alabama governor; U.S. district court judge Religious afFILIATION: Episcopalian

Sources: Who Was Who 1966, 650; Case and Comment 1914-15, 83

\section{NAME: Alton Brooks Parker}

Year/Place of Birth: 1852, New York

EduCATION: LL.B., Albany Law School, 1873

Year/STATE of Bar admission: 1877, New York

CAREer highlights: Practiced law in Kingston, N.Y.; first assistant postmaster general; justice, Supreme Court of New York; court of appeals; chief justice, appellate division, N.Y. court of appeals; unsuccessful candidate for president on Democratic ticket; member, Parker, Marshall, Miller \& Auchincloss

SOURCES: Who Was Who 1966, 934; Rogers 1932, 140-45; Obituary of Mrs. Alton B. Parker, New York Times, 3 April 1917, 13, col. 4

NAme: George Record Peck

YeAr/Place of BIRTh: 1843, New York

EDUCATION: Common schools

YeAR/STATE OF BAR ADMISSION: 1866, Kansas

CAREER HIGHLIGHTS: served in Wisconsin infantry; practiced in Kansas; general solicitor, A.T. \& S.F. R.R. Co.; general counsel, C. M. and St. P. Railway; U.S. attorney, Kansas; president, ABA

SOURCES: Who Was Who 1966, 952; Rogers 1932, 136-39; Obituary, New York Times, 23 Feb. 1923, 13, col.5

\section{NAME: Francis Lynde Stetson}

Year/Place of Birth: 1846 , New York

EduCATION: A.B., Williams College, 1867; LL.B., Columbia, 1869

YEAR OF BAR ADMISSION: 1869

Career Highlights: Member, Stetson, Jennings \& Russell; general counsel to Int'l Mercantile Marine Co., North Pacific Railway Co., Southern R.R. Co., U.S. Rubber Co.

SOURCES: Who Was Who 1966, 1180; Martindale Hubbell Law Directory 1920

\section{NAmE: Ezra Ripley Thayer}

YeAR/Place of BIRTH: 1866, Massachusetts

EduCation: A.B., Harvard, 1888; LL.B., 1891 
YeAR/STATE OF BAR ADMISSION: 1891, Massachusetts

Career highlights: Member, Brandeis, Dunbar \& Nutter; and Storey, Thorndike, Palmer \& Thayer; professor of law and dean, Harvard Law School

SOURCES: Who Was Who 1966, 1226; Harvard Law School Association 1916

NAME: Henry St. George Tucker

Year/Place OF Birth: 1853 , Virginia

EduCATION: A.M., Washington and Lee, 1875; B.L., 1876

YEAR/STATE OF BAR ADMISSION: 1876, Virginia

CAReer highlights: Practiced law in Virginia; member of Congress; professor of law and dean, Washington and Lee University; taught at Columbian (now George Washington University) Law School; president of the ABA

Religious affiliation: Presbyterian

SOURCES: Who Was Who 1966, 1256; Bryson 1982, 618; Rogers 1932, $131-35$ 


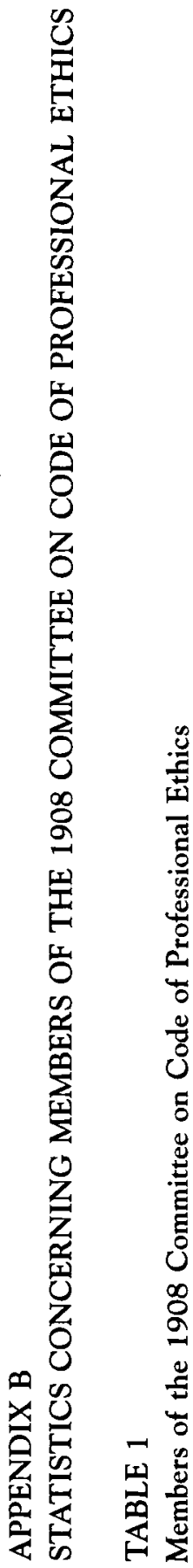

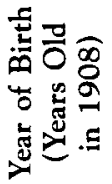

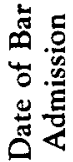

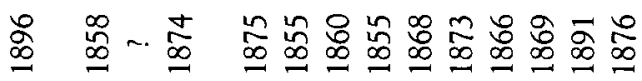

㞼高

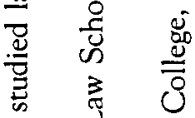

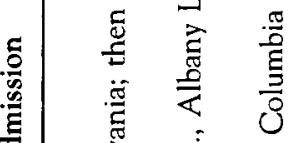

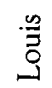

$\overline{\bar{g}}$

$\frac{\pi}{2} \stackrel{0}{3}$

范

8

壳

总

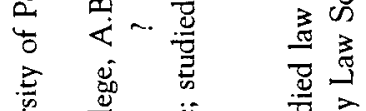

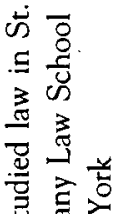

के

总

言

चี

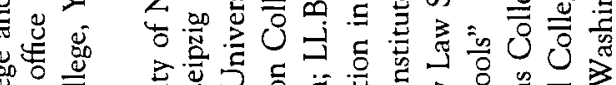

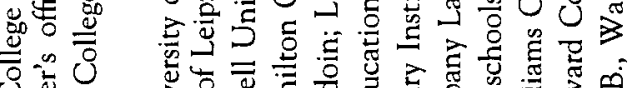

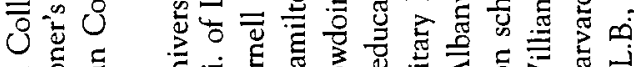

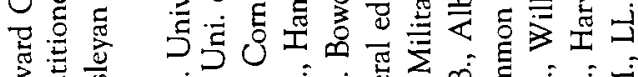

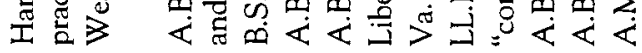

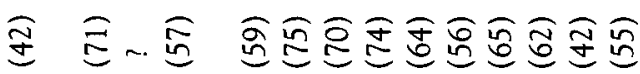

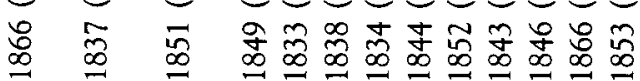

ڤँّ

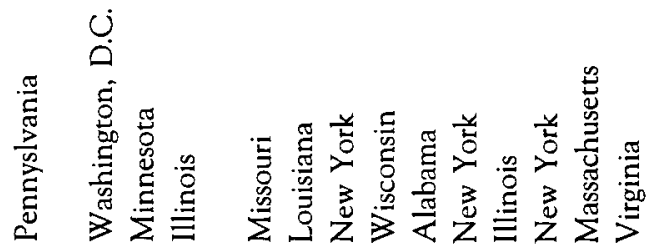

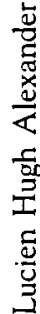

$\stackrel{\text { घ. }}{\underline{\underline{u}}}$

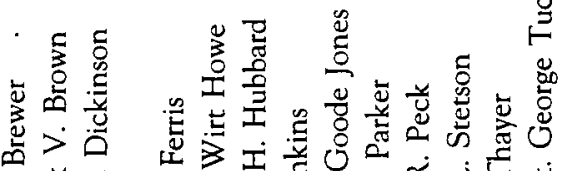

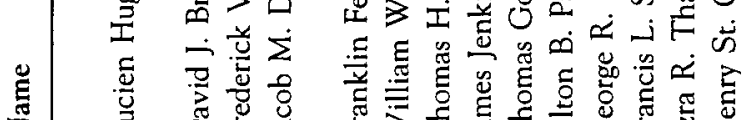


TABLE 2

Summary Statistics

\begin{tabular}{lr}
\hline Committee Members & \\
\hline Residence $^{\mathrm{a}}$ & \\
In Northeast & $36 \%$ \\
In South & $29 \%$ \\
In Midwest or West & $36 \%$ \\
Education $^{\mathrm{a}}$ & $73 \%$ \\
$\quad$ College degree & $46 \%$ \\
LL.B degree $^{\text {Average age }}$ & 61 \\
Bar admission & \\
Earliest year & 1860 \\
Latest year & 1891 \\
Average year & 1871 \\
\hline
\end{tabular}

${ }^{a}$ Includes only members with known information. 


\section{REFERENCES}

Abbot, Everett V. 1902. Some Actual Problems of Professional Ethics. Harvard Law Review 15:714-24.

- 1913. Justice and the Modern Law. Boston: Houghton Mifflin Company.

Abel, Richard. 1989. American Lawyers. New York: Oxford University Press.

Alabama State Bar Association. 1887a. Proceedings of the Tenth Annual Meeting. In Alabama Bar Association Reports, 1886-91. Montgomery: Brown Printing.

- 1887b. Code of Ethics. In Alabama Bar Association Reports, 1886-91. Montgomery: Brown Printing.

Alexander, Lucien. 1908. Memorandum for Use of ABA's Committee to Draft Canons of Professional Ethics. Chicago: American Bar Association.

American Bar Association. 1908. Floor Debate. In Report of the Thirty-First Annual Meeting of the American Bar Association. Baltimore: Lord Baltimore Press.

- 1909. William Wirt Howe. Reports of the American Bar Association 34:622-23.

Auerbach, Jerold. 1971. Enmity and Amity: Law Teachers and Practitioners, 1920-1922.

In Law in American History, ed. Donald Fleming and Bernard Bailyn. Boston: Little, Brown.

- 1974. Unequal Justice: Lawyers and Social Change in Modern America. New York: Oxford University Press.

Baldwin, Simeon. 1903. Legal Ethics. Lecture delivered before the Students of the Law Department of Union University. N.p.

- 1908. The New American Code of Legal Ethics. Columbia Law Review 8:541-47.

Bloomfield, Maxwell. 1979. David Hoffman and the Shaping of a Republican Legal Culture. Maryland Law Review 38:673-88.

Brewer, David. 1904a. The Ethical Obligations of the Lawyer as a Lawmaker. American Lawyer 19:299-300.

—. 1904b. Legal Ethics: Address Delivered at Commencement of Albany Law School. Albany, N.Y.: Union University.

Brodhead, Michael J. 1994. David J. Brewer: The Life of a Supreme Court Justice, 1837-1910. Carbondale: Southern Illinois University Press.

Bryson, W. Hamilton. 1982. Legal Education in Virginia: 1779-1979. Charlottesville: University Press of Virginia.

Case and Comment. 1914-15. Hon. Thomas Goode Jones. 21:83-84.

Chroust, Anton-Hermann. 1965. The Rise of the Legal Profession in America: The Revolution and Post-Revolutionary Era. Vol. 2. Norman: University of Oklahoma Press.

Committee on Code of Professional Ethics. 1906. Report. In Report of the Twenty-Ninth Annual Meeting of the ABA. Baltimore: Lord Baltimore Press.

- 1907. Report. In Report of the Thirtieth Annual Meeting of the American Bar Association. Baltimore: Lord Baltimore Press.

- 1908. Final Report. In Report of the Thirty-First Annual Meeting of the American Bar Association. Baltimore: Lord Baltimore Press.

- 1918. Report of the Committee on Professional Ethics. ABA Journal 4:480-99.

Costigan, George P., Jr. 1917. Cases and Other Authorities on Legal Ethics. St. Paul, Minn.: West.

Current Topics and Notes. 1917. American Law Review 51:752.

Dickinson, Jacob M. 1884. Advisability and Feasibility of Codification. Tennessee Bar Association 3:179.

Drinker, Henry S. 1953. Legal Ethics. New York: Columbia University Press.

Forsyth, William. 1881. Hortensius. Jersey City, N.J.: Frederick D. Linn. 
Frank, John P. 1965. The Legal Ethics of Louis D. Brandeis. Stanford Law Review 17:683-709.

Freedman, Monroe. 1991. Ethical Ends and Ethical Means. Journal of Legal Education 41:55-64.

Freidson, Eliot. 1986. Professional Powers: A Study of the Institutionalization of Formal Knowledge. Chicago: University of Chicago Press.

Fried, Charles. 1976. The Lawyer as a Friend. Yale Law Journal 85:1060-89.

Galambos, Louis. 1970. The Emerging Organizational Synthesis in Modern American History. Business History Review 44:279-320.

Gawalt, Gerard W., ed. 1984. The New High Priests: Lawyers in Post-Civil War America. Westport, Conn.: Greenwood Press.

Georgia Bar Association. 1889. Report of the Committee on Legal Ethics. In Georgia Bar Association Proceedings. Macon: The Association.

- 1896. Report of the Commitree on Professional Ethics. In Georgia Bar Association Proceedings. Macon: The Association.

Gordon, Robert W. 1981. Historicism in Legal Scholarship. Yale Law Joumal 90:1017-56.

. 1983. Legal Thought and Legal Practice in the Age of American Enterprise. In Professionals and Professional Ideologies in America, ed. G. Geison. Chapel Hill: University of North Carolina Press.

- 1984. The Ideal and the Actual in the Law: Fantasies and Practices of NYC Lawyers: 1870-1910. In Gawalt 1984.

- 1988. The Independence of Lawyers. Boston University Law Review 68:1-83.

- 1990. Corporate Law Practice as a Public Calling. Maryland Law Review 49:255-92.

Haber, Samuel. 1991. The Quest for Authority and Honor in the American Professions, 1750-1900. Chicago: University of Chicago Press.

Harbaugh, William H. 1973. Lawyer's Lawyer: The Life of John W. Davis. New York: Oxford University Press.

Harvard Law School Association. 1916. Ezra Ripley Thayer: An Estimate of His Work as Dean of the Harward Law School. Cambridge: Harvard Law School.

Hixson, William B. 1972. Moorfield Storey and the Abolitionist Tradition. New York: Oxford University Press.

Hobson, Wayne K. 1984. Symbol of the New Profession: Emergence of the Large Law Firm, 1870-1915. In Gawalt 1984.

Hoffman, David. [1836] 1972. A Course of Legal Study. 2d ed. New York: Arno Press. Hofstadter, Richard. 1955. The Age of Reform: From Bryan to FDR. New York: Knopf.

Horwitz, Morton. 1992. Holmes in American Legal Thought. In The Legacy of Oliver Wendell Homes, Jr., ed. Robert W. Gordon. Stanford, Calif.: Stanford University Press.

Horwitz, Morton J. 1992. The Transformation of American Law, 1870-1960. New York: Oxford University Press.

Howe, Mark DeWolfe. 1932. Portrait of an Independent. Boston: Houghton Mifflin.

Howe, William Wirt. 1899. Professional Ethics. Virginia Law Review 8:507-20.

- 1907. Corporation Lawyers. Yale Law Journal 16:497-503.

Hurst, James Willard. 1950. The Growth of American Law: The Law Makers. Boston: Little, Brown.

-1956. Law and the Conditions of Freedom in the Nineteenth-Century United States. Madison: University of $W$ isconsin Press.

Illinois Bar Association. 1909. Ethics Report. Springfield: Illinois State Bar Association. 
Johnson, John W. 1981. American Legal Culture, 1908-1940. Westport, Conn.: Greenwood Press.

Johnson, William. 1978. Schooled Lawyers: A Study in the Clash of Professional Cultures. New York: New York University Press.

Jones, Walter Burgwyn. 1922. First Code of Ethics Adopted in the United States. ABA Journal 8:111-13.

Larson, Magali Sarfatti. 1977. The Rise of Professionalism: A Sociological Analysis. Berkeley and Los Angeles: University of California Press.

Lewis, William Draper. 1900. The Proper Preparation for the Study of Law. American Law Register 11:633-46.

1913. The Social Sciences as the Basis of Legal Education. University of Pennsyluania Law Review 61:531-39.

Link, Arthur S., and Richard L. McCormick. 1983. Progressivism. Arlington Heights, Ill.: Harlan Davidson.

Luban, David. 1988. Lawyers and Justice. Princeton, N.J.: Princeton University Press.

Mason, Alpheus Thomas. 1936. Brandeis and the Modern State. Washington, D.C.: National Home Library Foundation.

Matzko, John A. 1984. The Best Men of the Bar: The Founding of the American Bar Association. In Gawalt 1984.

Menkel-Meadow, Carrie. 1996a. The Trouble with the Adversary System in Post-Modern, Multi-Cultural World. William and Mary Law Review 38:5-44.

-1996b. Moral Boundaries: A Political Argument for an Ethic of Care. New York University Review of Law and Social Change. 22:265-93

Mowry, Duane. 1902. Commercialism in the Practice of Law. Albany Law Journal 64:359-60.

Nelson, Robert L., and David M. Trubek. 1992. New Problems and New Paradigms in Studies of the Legal Profession. In Nelson, Trubek, and Solomon 1992.

Nelson, Robert L., David M. Trubek, and Rayman L. Solomon, eds. 1992. Lawyers' Ideals/Lawyers' Practices: Transformations in the American Legal Profession. Ithaca, N.Y.: Cornell University Press.

Oakes, Edwin S. 1911. The Ethics of Advocacy in an Unjust Cause. Law Times 131:40-65.

Parker, Alton B. 1913. The Safe and Right Direction for Progress. Ohio Law Report 11:141-56.

Patterson, L. Ray. 1980. Legal Ethics and the Lawyers' Duty of Loyalty. Emory Law Journal 29:909-69.

Paul, Arnold. 1965. Conservative Crises and the Rule of Law. Ithaca, N.Y.: Cornell University Press.

Pearce, Russell G. 1992. Rediscovering the Republican Origins of the Legal Ethics Codes. Georgetown Journal of Legal Ethics 6:241-82.

Pennsylvania Bar Association. 1926. Thirty-Second Annual Report. Harrisburg: Pennsylvania

Pepper, Stephen L. 1986. The Lawyer's Amoral Ethical Role: A Defense, A Problem, and Some Possibilities. American Bar Foundation Research Journal 1986:613-35.

Rodgers, Daniel. 1982. In Search of Progressivism. Reviews of American History 10:113-32.

Rogers, James Grafton. 1932. American Bar Leaders: Biographies of the Presidents of the ABA 1878-1928. Chicago: American Bar Association.

Rogers, Showell. 1899. The Ethics of Advocacy. Law Quarterly. 59:259-80.

Ross, Dorothy. 1991. The Origins of American Social Science. Cambridge: Cambridge University Press. 
Schlegel, John Henry. 1985. Between the Harvard Founders and the American Legal Realist: The Professionalization of the American Law Professor. Joumal of Legal Education 35:311-25.

Schneyer, Theodore. 1984. Moral Philosophy's Standard Misconception of Legal Ethics. Wisconsin Law Review 1529-72.

-1989. Professionalism as Bar Politics. Law and Social Inquiry 14:677-737.

1991. Some Sympathy for the Hired Gun. Journal of Legal Education 41:11-27. 1992. Professionalism as Politics: The Making of a Modern Legal Ethics Code. In Nelson, Trubek, and Solomon 1992.

Schudson, Michael. 1977. Public, Private, and Professional Lives: The Correspondence of David Dudley Field and Samuel Bowles. American Journal of Legal History 21:191-211.

Schwartz, Murray. 1978. The Professionalism and Accountability of Lawyers. California Law Review 66:669-97.

Sharswood, George. 1860. An Essay on Professional Ethics. 2d ed. Philadelphia: T. \& J. W. Johnson.

Siegel, Stephen A. 1990. Historism in Late Nineteenth-Century Constitutional Thought. Wisconsin Law Review 1990:1431-1547.

1. 1995. Joel Bishop's Orthodoxy. Law \& History Review 13:215-59.

Sims, Henry Upson. 1925. The First Problem in Professional Ethics. ABA Journal 11:63-64.

Simon, William H. 1978. The Ideology of Advocacy: Procedural Justice and Professional Ethics. Wisconsin Law Review 1978:29-144.

- 1984. Visions of Practice in Legal Thought. Stanford Law Review 36:469-507. 1988. Ethical Discretion in Lawyering. Harvard Law Review 101:1083-1145.

. 1994. The Dark Secret of Progressive Lawyering: A Comment on Poverty Law Scholarship in the Post-Modern, Post-Reagan Era. University of Miami Law Review 48:1099-1114.

- 1998. The Practice of Justice: A Theory of Lawyers' Ethics. Cambridge, Mass.: Harvard University Press.

Sims, Henry Upson. 1925. The First Problem in Professional Ethics. ABA Joumal 11:63-64.

Spillenger, Clyde. 1996. Elusive Advocate: Reconsidering Brandeis as People's Lawyer. 1996. Yale Law Joumal 105:1445-1535.

Starr, Paul. 1982. The Social Transformation of American Medicine. New York: Basic Books.

Stetson, Francis Lynde. 1909. The Lawyer's Livelihood. The Green Bag. 21:45-57.

Stevens, Robert. 1983. Law School: Legal Education in America from the 1850's to the 1980's. Chapel Hill: University of North Carolina Press.

Storey, Moorfield. 1911. The Reform of Legal Procedure. New Haven, Conn.: Yale University Press.

Strum, Philippa. 1984. Brandeis: Justice for the People. Cambridge, Mass.: Harvard University Press.

- 1993. Brandeis: Beyond Progressivism. Lawrence: University Press of Kansas.

Thayer, Ezra Ripley. 1911. Should the Law Teacher Practice Law? Harvard Law Review 25:269-73.

- 1913. Letter to H. S. Gragin, 11 September 1913. Thayer Correspondence Files, vol. 29. Harvard University Archives.

Tucker, Henry St. George. 1844. A Few Lectures on Natural Law. Charlottesville, Va.: University Press.

- 1911a. Have the Corporations Been Law Abiding? New Haven: N.p. 

1911b. The Lawyer as a Business Man. American Law School Review 3:109-15.
1916. Women's Suffrage by Constitutional Amendment. New Haven, Conn.: Yale University Press.

Wasserstrom, Richard. 1975. Lawyers as Professionals: Some Moral Issues. Human Rights $5: 1-24$.

Weinreb, Lloyd L. 1987. Natural Law and Justice. Cambridge, Mass.: Harvard University Press.

White, G. Edward. 1978. From Sociological Jurisprudence to Realism. In Patterns of Legal Thought, ed. G. Edward White. Indianapolis: Bobbs-Merrill.

White, Morton Gabriel. 1949. Social Thought in America: The Revolt Against Formalism. New York: Viking Press.

Wiebe, Robert H. 1967. The Search for Order, 1877-1920. New York: Hill and Wang.

Wilkins, David. 1998. Everyday Practice Is the Troubling Case: Confronting Context in Legal Ethics. In Everyday Practices and Trouble Cases, ed. Austin Sarat, Marianne Constable, David Engel, Valerie Hans, and Susan Lawrence. Evanston, Ill.: Northwestern University Press.

Wolf, Susan. 1983. Ethics, Legal Ethics and the Ethics of Law. In The Good Lawyer: Lawyers' Roles and Lawyers' Ethics, ed. David Luban. Totowa, N.J.: Rowman and Allanheld.

Wolverton, Charles E. 1900. The Ethics of Advocacy. American Law 8:62-67. 